\title{
Article
}

\section{Holistic View on Synthetic Natural Gas Production: A Technical, Economic and Environmental Analysis}

\author{
Estefania Vega Puga ${ }^{1, *(\mathbb{D}}$, Gkiokchan Moumin ${ }^{1}\left(\mathbb{0}\right.$, Nicole Carina Neumann ${ }^{1}{ }^{(}$, Martin Roeb ${ }^{1}$, Armin Ardone ${ }^{2}$ \\ and Christian Sattler ${ }^{1}[\mathbb{C}$
}

1 Institute of Future Fuels, German Aerospace Center, Linder Hoehe, 51147 Cologne, Germany; gkiokchan.moumin@dlr.de (G.M.); Nicole.Neumann@dlr.de (N.C.N.); martin.roeb@dlr.de (M.R.); Christian.Sattler@dlr.de (C.S.)

2 Institute for Industrial Production, Karlsruhe Institute of Technology, Hertzstr. 16, 76187 Karlsruhe, Germany; armin.ardone@kit.edu

* Correspondence: estefania.vegapuga@dlr.de; Tel.: +49-2203-601-3508

check for updates

Citation: Vega Puga, E.; Moumin, G.; Neumann, N.C.; Roeb, M.; Ardone, A.; Sattler, C. Holistic View on Synthetic Natural Gas Production: A Technical, Economic and Environmental Analysis. Energies 2022, 15, 1608. https://doi.org/ $10.3390 /$ en15051608

Academic Editors: Federica Raganati and Paola Ammendola

Received: 11 January 2022

Accepted: 11 February 2022

Published: 22 February 2022

Publisher's Note: MDPI stays neutral with regard to jurisdictional claims in published maps and institutional affiliations.

Copyright: (C) 2022 by the authors. Licensee MDPI, Basel, Switzerland. This article is an open access article distributed under the terms and conditions of the Creative Commons Attribution (CC BY) license (https:// creativecommons.org/licenses/by/ $4.0 /)$.

\begin{abstract}
Synthetic Natural Gas (SNG) is the most researched option for a Power-to-Fuel pathway in Germany after hydrogen, having the advantage of being compatible with the existing infrastructure. However, it is not clear under which conditions SNG is economically and environmentally advantageous compared to natural gas usage, since this is determined by a complex interplay of many factors. This study analyzes the technical, economic and environmental aspects of a pilot SNG plant to determine the key parameters for profitable and sustainable operation. The SNG plant was simulated in Aspen Plus ${ }^{\circledR}$ with $\mathrm{CO}_{2}$ from biogas production as a feedstock and with hydrogen provided by a $1 \mathrm{MW}_{\mathrm{el}}$ electrolyzer unit. A life cycle analysis (LCA) was undertaken considering several impact categories with a special focus on global warming potential (GWP). An SNG cost of $0.33-4.22 € / \mathrm{kWh}_{\text {th }}$ was calculated, depending on factors such as operational hours, electricity price and type of electrolyzer. It was found that the $\mathrm{CO}_{2}$ price has a negligible effect on the SNG cost, while the electricity is the main cost driver. This shows that significant cost reductions will be needed for $\mathrm{SNG}$ to be competitive with natural gas. For the investigated scenarios, a $\mathrm{CO}_{2}$ tax of at least $1442 € / \mathrm{t}$ was determined, calling for more drastic measures. Considering the global warming potential, only an operation with an emission factor of electricity below $121 \mathrm{~g} \mathrm{CO}_{2}-\mathrm{eq} / \mathrm{kWh}_{\mathrm{el}}$ leads to a reduction in emissions. This demonstrates that unless renewable energies are implemented at a much higher rate than predicted, no sustainable SNG production before 2050 will be possible in Germany.
\end{abstract}

Keywords: techno economic analysis; LCA; synthetic natural gas; CCU; Power-to-Gas

\section{Introduction}

In view of increased anthropogenic emissions and the imminent threat of climate change, Germany has committed to reduce its Greenhouse Gas (GHG) emissions by 2030 by at least $65 \%$ compared to 1990 s levels, and achieve GHG neutrality by 2045 [1]. To meet these targets, different strategies, policies and instruments must be developed considering that, while the transformation towards renewable energy sources is already well advanced, concepts for extensive industry decarbonization exist mainly isolated. In the Power-to-Fuel (PtF) concept it is foreseen to produce chemical energy carriers by using electricity and $\mathrm{CO}_{2}$, thus offering a way for storing fluctuating renewable electricity while utilizing $\mathrm{CO}_{2}$ that would otherwise be emitted into the atmosphere. In such a system, $\mathrm{CO}_{2}$ can be separated from flue gas streams of industrial processes or power plants. $\mathrm{CO}_{2}$-based fuels, also known as electro fuels, are of particular interest, since they represent climate-friendly alternatives to conventional fossil fuels, while simultaneously using the existing infrastructure and vehicles [2].

Power-to-Synthetic Natural Gas (SNG), also known as Power-to-Gas (PtG) technology, generates methane via a two-step process: $\mathrm{H}_{2}$ production by water electrolysis and $\mathrm{CH}_{4}$ 
generation via $\mathrm{H}_{2}$ and $\mathrm{CO}_{2}$ conversion according to the Sabatier reaction [3]. The resulting $\mathrm{CH}_{4}$ is commonly referred to as $\mathrm{SNG}$, since methane is the principal component of natural gas. SNG can be injected into the existing natural gas network, used as Compressed Natural Gas (CNG) motor fuel and in all other established natural gas facilities. In recent years, research and pilot projects dealing with the production of renewable fuels have rapidly increased. In Europe, Germany holds the largest share of realized demonstration projects, where, after hydrogen methane, the second most researched is the Power-to-Fuel option [4-7]. Regarding methanation technology, of special importance is the Audi e-gas plant in Werlte, which is presently the largest industrial PtG plant in the world $\left(6 \mathrm{MW}_{\mathrm{el}}\right)$ and has been operating since 2013 [8]. Larger plants are under construction.

Several techno-economic analyses focusing on Power-to-SNG (PtSNG) technology have been conducted [2,8-14]. These studies mostly focus on different technological options within the system (e.g., electrolyzer technology and source of $\mathrm{CO}_{2}$ ) as well as on products and services provided (e.g., CNG for mobility or injection in the gas network) in a given regulatory context. Schiebahn, et al. [15] presented a technology overview on different PtG routes and compared power-to-hydrogen and power-to-methane in terms of future market options, with a SNG feed-in cost of $0.23 € / \mathrm{kWh}_{\mathrm{SNG}}$ using wind energy and an $84 \mathrm{GW}_{\mathrm{el}}$ electrolyzer. Buchholz, et al. [16] studied the integration of a methanation reactor with an alkaline electrolyzer and a lignite fired power plant to produce SNG for subsequent injection in the gas grid. The plant efficiency was estimated at $53 \%$ and the SNG cost at $0.72-1.08 € / \mathrm{kWh}$. These high prices are attributed to high electrolyzer costs. Giglio, et al. [17] examined SNG production on a plant with $10 \mathrm{MW}_{\mathrm{el}}$ high temperature electrolysis and found SNG costs of $0.048-0.094 € / \mathrm{kWh}_{\mathrm{SNG}}$ depending on $\mathrm{CO}_{2}$ and electricity prices. Parra and Patel [18] calculated the levelized cost of SNG (LCOES) production for different system ratings from $25 \mathrm{~kW}$ to $1000 \mathrm{MW}$, using different electrolyzer technologies within the Swiss context. The authors estimated a SNG LCOES at $0.13 € / \mathrm{kWh}$ SNG when using a $1 \mathrm{MW}$ alkaline electrolyzer and showed that for all the examined scenarios alkaline technology leads to a lower SNG cost than PEM. Overall, published literature shows a broad range of costs and a wide variety of cost calculating methodologies, therefore a study outlining the different findings and assumptions of each of the studies is of primary importance but, nevertheless, currently missing.

Regarding the environmental performance of PtG systems, a limited number of published literature has utilized the Life Cycle Analysis (LCA) method, and these have only focused on climate change without reporting on other environmental aspects [19-21]. Hoppe, et al. [21] compared the global warming potential (GWP) of $\mathrm{CO}_{2}$-based SNG with conventionally produced natural gas in transport and determined that SNG produced with wind power would lead to lower GWP than using natural gas in either transport or chemical production. Reiter and Lindorfer [19] used an LCA to compare PtSNG with conventional gas supply and concluded that PtSNG reduced the GWP of fuel only if renewable energy was used for electrolysis. Sternberg and Bardow [20] also performed an LCA of PtSNG technology and determined that the environmental threshold for electricity supply is $0.082 \mathrm{~kg} \mathrm{CO} 2-\mathrm{eq} / \mathrm{kWh}_{\mathrm{el}}$ so that SNG production is more environmentally beneficial than conventional natural gas usage. In both cases, no techno-economic analysis was performed. Collet, et al. [22] presented an economic and environmental assessment of PtSNG technology combined with anaerobic digestion. The authors found SNG costs of $0.096-0.104 € / \mathrm{kWh}_{\mathrm{SNG}}$ for different plant configurations and determined that continuous PtSNG generates more greenhouse gases than direct injection, but intermittent operation with use of renewable electricity can significantly reduce GHG emissions. Parra, et al. [23] performed a techno-economic and environmental analysis on PtG systems participating in the Swiss wholesale electricity market, which included value-adding services in addition to fuel production. Authors determined that none of the systems is economically profitable if only selling fuels, and on an environmental level, only renewable electricity input into the electrolysis leads to environmental benefits compared to conventional natural gas 
production. In both studies, no detailed modeling of the technical aspects of the plant were included.

The present work combines all the aforementioned research areas. The goal is to examine the techno-economic and environmental characteristics of SNG synthesis in the frame of PtG technology, providing an in depth understanding of factors affecting the technological, economic and environmental feasibility of the proposed concept. Initially we present a model PtSNG plant using the Aspen Plus ${ }^{\circledR}$ software which considers all relevant process units and technical requirements. Next, in the economic assessment the net production cost of the product SNG is estimated utilizing the annualized cost method, and obtained results are compared to current natural gas costs and published literature values on the same process. Different scenarios are discussed in order to evaluate at which conditions the pilot plant concept would be economically competitive. Finally, we use an LCA to perform the comparative environmental analysis of PtSNG and natural gas conventional production. In the frame of the environmental assessment, emission factor values of the electricity supply, under which PtSNG is more environmentally beneficial than natural gas fossil-based production, are identified. For all three aspects, relevant data are provided in the Supplementary Materials.

\section{Methodology}

The system boundaries as well as the most relevant material and energy flows are shown schematically in Figure 1. In the case of the technical analysis only electricity, water, and compressed $\mathrm{CO}_{2}$ are input flows while $\mathrm{SNG}$ is obtained as the product. The $\mathrm{CO}_{2}$ is obtained in the Reference case from a biogas production plant. The economic and environmental analyses have a broader system boundary, in which additional electricity and fuel for the $\mathrm{CO}_{2}$ compression and transportation are considered as inputs. At the same time an additional stream of emissions from the transport is included.

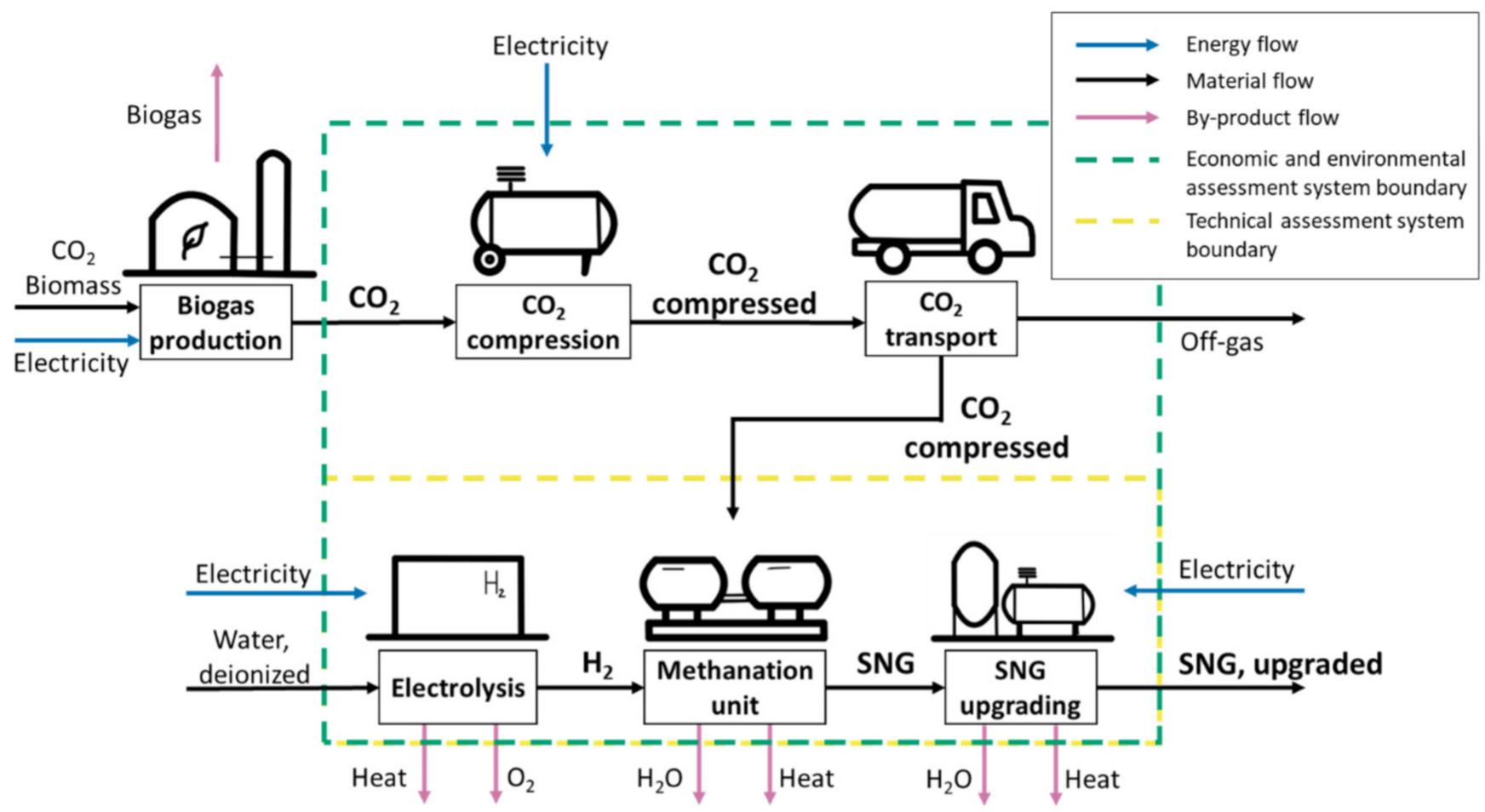

Figure 1. Schematic representation of considered system boundaries for the technical, economic and environmental assessment in the Reference case. 


\subsection{Technical Assessment}

This chapter describes the basic assumptions and the properties used in the simulation of the pilot PtSNG plant. The simulation was done in the Aspen Plus ${ }^{\circledR}$ v10 software [24]. Information on the characterization of the kinetic model used for the 1D pseudo-homogenous reactor modeling is also provided. Next, the product SNG is assessed to ensure it complies with standards for injection in the German natural gas network. Finally, mass and energy flows as well as performance metrics are presented and compared to literature data.

\subsubsection{Process Description}

In general, the production of SNG consists of three main steps: hydrogen production, methanation, and gas upgrading. In this study initially, hydrogen is generated using electrolysis. The proposed concept utilizes a commercially available $1 \mathrm{MW}_{\mathrm{el}}$ PEM electrolyzer because of its highly dynamic operational capabilities. Secondly, the produced hydrogen is mixed with $\mathrm{CO}_{2}$ in a stoichiometric ratio of $4: 1$ and the mixture is fed into the methanation unit. Then, the gas exiting the methanation unit is dried and pressurized in order to comply with the German synthetic natural gas DVGW G 260 standard [25] for subsequent injection into the natural gas network. The inputs of the process are distilled water, carbon dioxide and electricity, while the outputs are SNG and the by-products oxygen and heat. The $\mathrm{CO}_{2}$ is assumed to originate from a biomethane upgrading plant and is transported by truck to the pilot plant. Neither the carbon capture technology nor the infrastructure required for gas injection into the national network are considered within the process simulation.

\subsubsection{Simulation Model}

The model in Aspen Plus ${ }^{\circledR}$ is based on pure components to describe the chemical reactions and the properties of mixtures within the process. In this work the Peng-Robinson equation of state is used to describe the thermodynamic behavior, as it is widely applied in the fields of gas processing and synthetic hydrocarbon production [9,12,26,27]. Heat losses of reactors, heat exchangers and piping are neglected.

Figure 2 portrays the flowsheet of the entire PtSNG plant developed in Aspen Plus ${ }^{\circledR}$. The electrolysis unit is represented by a hierarchy block, while the methanation unit comprises two cooled Plug Flow Reactor (PFR) blocks with partial water removal in between, performed by a heat exchanger block and a separator block. The gas upgrading unit involves two heat exchanger blocks, a separator block and a compressor block. The following sections discuss in detail the modeling of each of the PtSNG plant's units. Stream tables of the Aspen Plus ${ }^{\circledR}$ simulation are available in the Supplementary Materials Section S1.

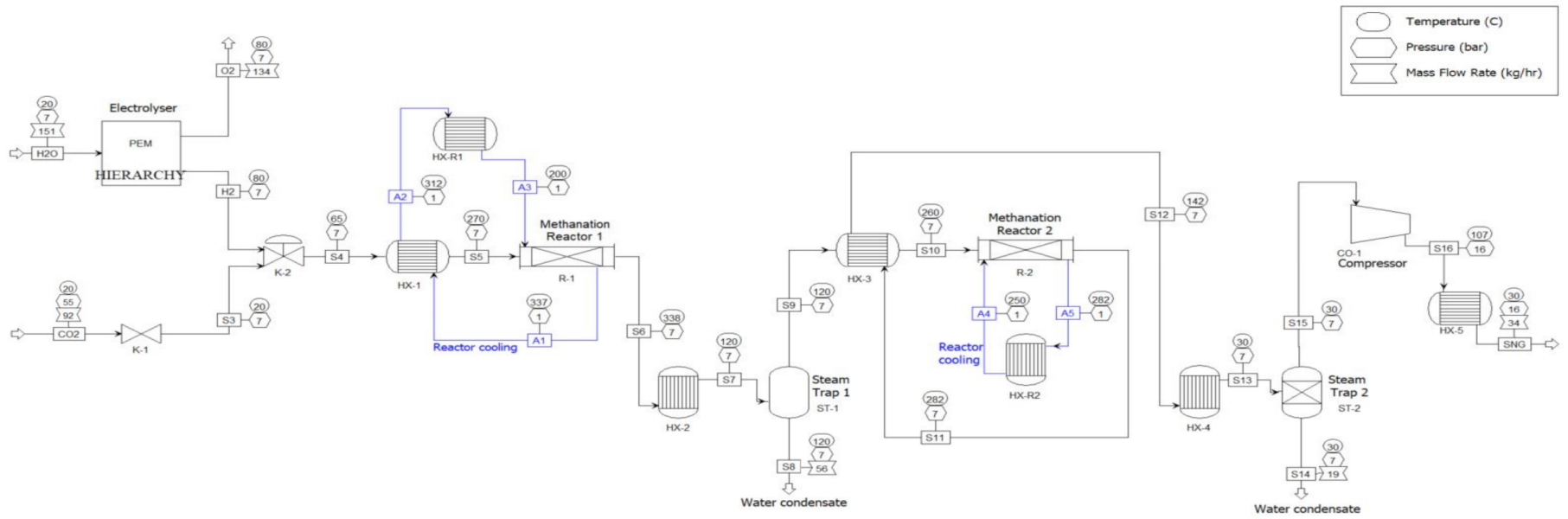

Figure 2. Flowsheet of the PtSNG plant. Flowsheet of the PEM hierarchy block is shown in Figure 3. 

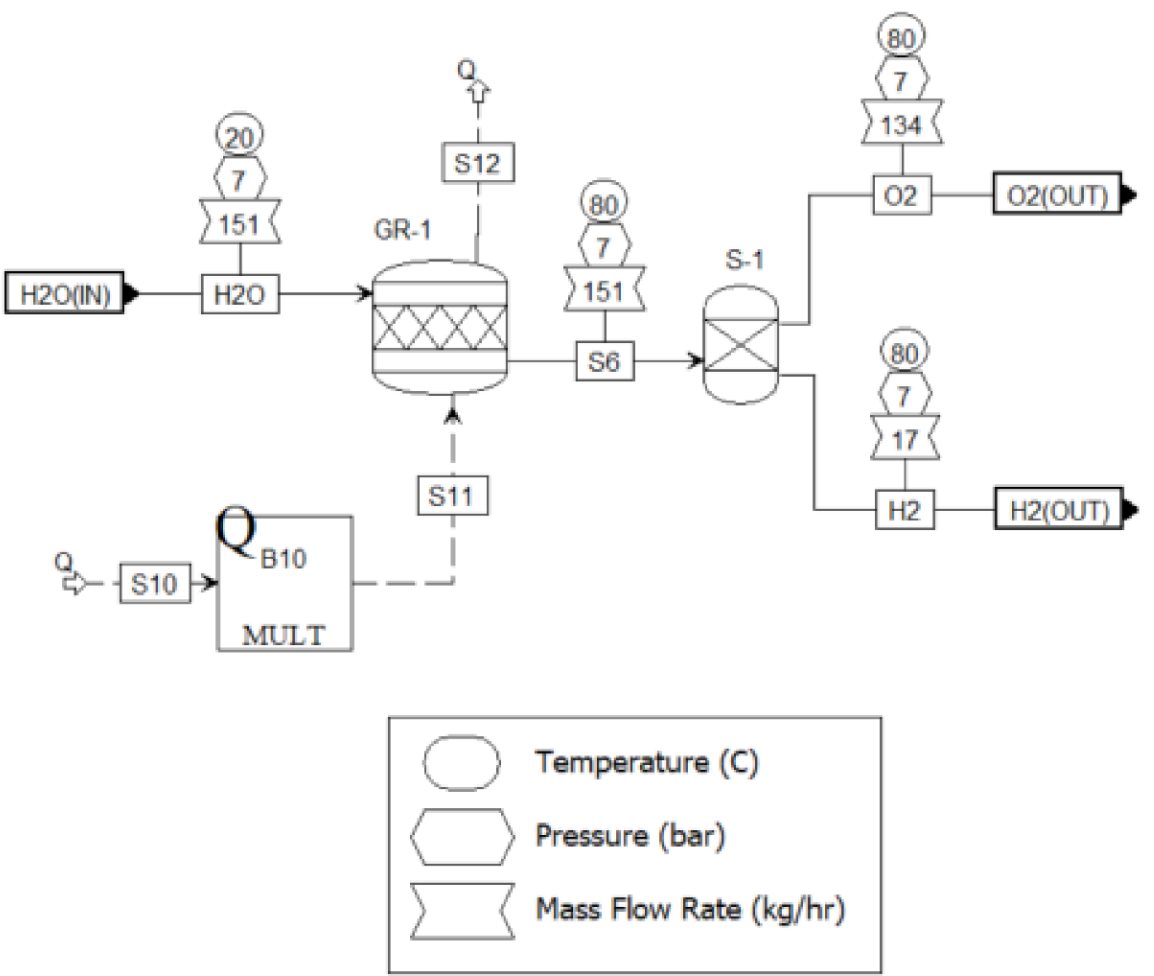

Figure 3. Flowsheet of the PEM electrolyzer.

\section{Electrolysis Unit}

The PEM electrolysis unit with operation conditions of 7 bar and $80^{\circ} \mathrm{C}$, was modeled by a Gibbs reactor block (GR-1) and a Splitter block (S-1) (Figure 3). A heat stream (S11) was used to represent the electric power coming in the electrolyzer and a heat multiplier block to indicate the efficiency of the electrolyzer. The water flow rate was calculated by using the design specification tool of Aspen Plus ${ }^{\circledR}$ and setting the heat flow coming out of the reactor GR-1 (S12) as zero. The use of a pressurized electrolyzer leads to the avoidance of compressor's investments to feed the hydrogen into the pressurized methanation unit. An energy demand of $4.88 \mathrm{kWh} / \mathrm{Nm}^{3} \mathrm{H}_{2}$ was used for electrolysis, corresponding to an electrical efficiency (Power to Lower Heating Value $\left(\mathrm{LHV}\right.$ of $\left.\mathrm{H}_{2}\right)$ ) of approximately 61.4\% [28]. The $1 \mathrm{MW}_{\mathrm{el}}$ PEM electrolyzer requires a DC electrical supply, therefore for direct connection to the power grid an $\mathrm{AC} / \mathrm{DC}$ inverter would be required. The simulation of the inverter is neglected in this study.

\section{Methanation Unit}

In this section, $\mathrm{CO}_{2}$ is hydrogenated according to the Sabatier reaction, which is favored by low temperatures and high pressures. The technology used in this study to design and model the methanation unit of the plant, is based on the patent of Solar Fuel GmbH [29], which is currently assigned to ETOGAS GmbH. The method produces SNG complying with the German technical and scientific association for gas and water (DVGW) standard G 260 [25] and consists of two successive reactor stages and partial water removal in between, ensuring high efficiency of the methanation reaction. Fixed-bed reactor technologies have been selected since they are commercially available from suppliers such as MAN, Outotec and ETOGAS [30]. Compared to an adiabatic reactor, a cooled fixedbed reactor has a lower temperature gradient and a lower reactor exit temperature, with similar conversion rates. All of which translates into catalyst's life extension, elimination of insulation need and high product yield [31].

In the pilot PtSNG plant, $\mathrm{CO}_{2}$ is initially decompressed to 7 bar, mixed in a stoichiometric ratio with $\mathrm{H}_{2}$, and then pre-heated to the methanation inlet temperature $\left(270{ }^{\circ} \mathrm{C}\right)$. For the pre-heating process, heat is recovered by the counterflow heat exchanger HX-1. 
The hot thermo-oil (Therminol-66) used in reactor R-1's cooling system is used as the heat source for the $\mathrm{H}_{2}$ and $\mathrm{CO}_{2}$ mixture in the heat exchanger $\mathrm{HX}-1$. During the system start-up, which is not considered in this work, the $\mathrm{H}_{2}$ and $\mathrm{CO}_{2}$ gas mixture must be heated externally, for example by high pressure steam. The first methanation reactor (R-1) is operated at 7 bar and exit temperature of $338{ }^{\circ} \mathrm{C}$. Water from the gas mixture exiting the first reactor stage is partially removed by cooling the gas to $120^{\circ} \mathrm{C}$, passing it through a steam trap (ST-1) and discharging the condensing water. The gas mixture from which water was removed is then pre-heated in heat exchanger $\mathrm{HX}-3$ to $260{ }^{\circ} \mathrm{C}$, by recovered heat from the exit gas of the second reactor stage (R-2). Similar to HX-1, during start up HX-3 will require an external heat source. The second reactor R-2 is operated at 7 bar and exit temperature of $282{ }^{\circ} \mathrm{C}$.

\section{Reactor Modeling}

A pseudo-homogenous and one-dimensional equation system or plug-flow modeling approach was applied for both reactors R-1 and R-2, which are similar but have different operating conditions. In this case, axial distribution of the gas species and temperature is considered, but radial profiles are neglected. Schlereth and Hinrichsen [32] demonstrated that a $1 \mathrm{D}$ reactor model is capable of describing qualitative trends and can be used for screening process conditions, hence this approach has been regarded as suitable for this study. The reactors R-1 and R-2 were modeled as Plug Flow Reactors (PFR), assuming no mass or heat transfer limitations in the catalyst, negligible radial temperature gradient in the catalyst and no coke formation in the reactors. Both reactors comprise a tube bundle, inside which the catalyst is located, and the feed gas is passed through, as well as a shell side where the cooling medium (thermo-oil) is circulated (Figure 4).

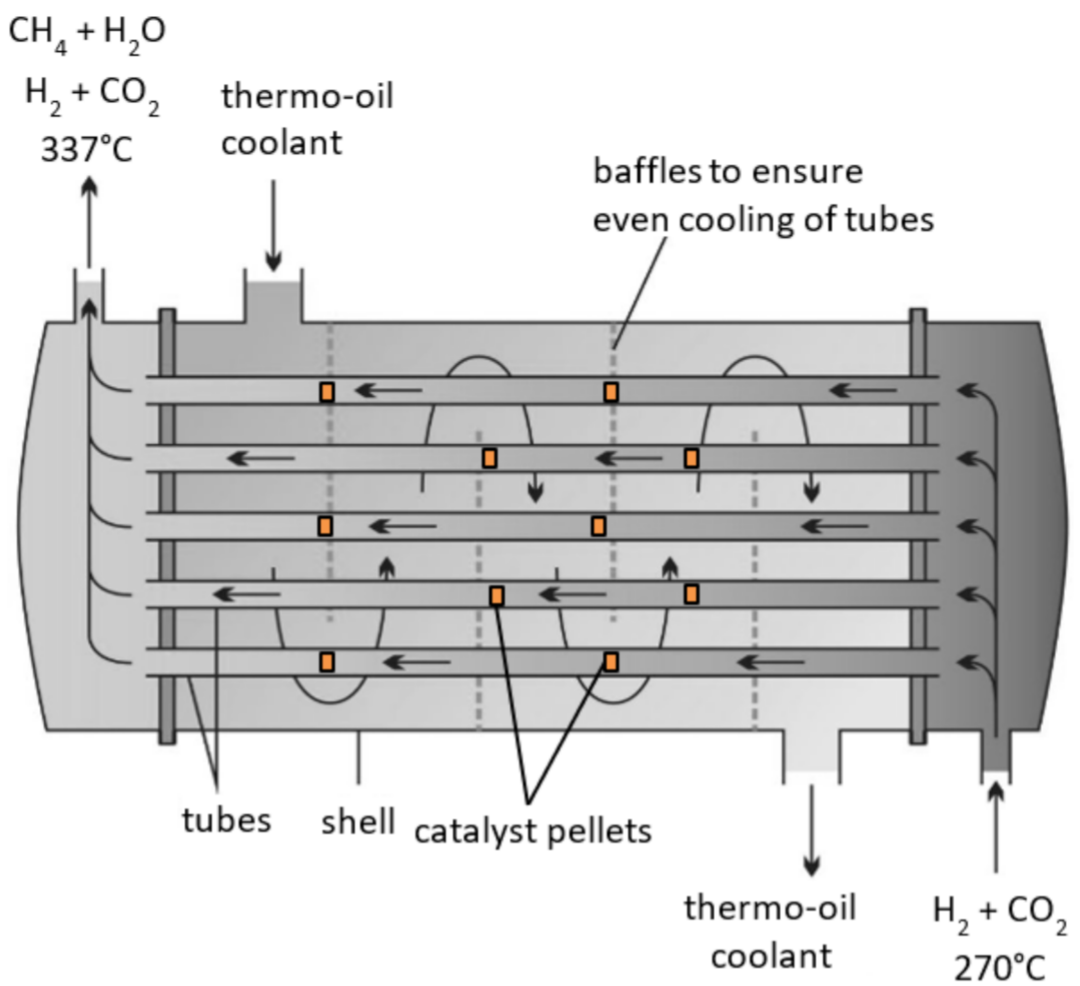

Figure 4. Schematic of reactor R-1. Adapted from Kuznik [33].

The catalyst used in the present work to determine the kinetics of the methanation reaction is ruthenium-based, which is the most promoting $\mathrm{CO}_{2}$ hydrogenation catalyst and functions well at low temperatures $\left(250-450{ }^{\circ} \mathrm{C}\right)$ [16]. Ruthenium-based catalysts are also less susceptible to poisoning by halogens and sulphur, than nickel-based ones, which may be present in $\mathrm{CO}_{2}$ from biogas [3]. The catalyst bed is characterized with the values given by Riogen manufacturer's information from a $0.5 \mathrm{wt} . \% \mathrm{Ru} / \mathrm{Al}_{2} \mathrm{O}_{3}$ catalyst, which is widely 
used for methanation. Catalyst particles are assumed to be spherical with an equivalent diameter $d_{\mathrm{P}}$ of $2.73 \mathrm{~mm}$, bulk density of $750 \mathrm{~kg} / \mathrm{m}^{3}$ and bed voidage of 0.4 .

The kinetic model developed by Falbo, et al. [34] was utilized, since it refers to the dataset that best fits the conditions of this work. This model is based on the power-law type equation developed by Lunde and Kester [35], a gas feed with a ratio of $\mathrm{H}_{2}: \mathrm{CO}_{2}$ of 4 , a $0.5 \mathrm{wt}$ \% $\mathrm{Ru} / \mathrm{Al}_{2} \mathrm{O}_{3}$ catalyst and high pressures relevant for $\mathrm{PtG}$ applications. Falbo, et al. [34] obtained the following rate expression:

$$
r_{\mathrm{CO}_{2}}=\frac{k}{1+\alpha P_{\mathrm{H}_{2} \mathrm{O}}}\left(\left[P_{\mathrm{CO}_{2}}\right]^{n}\left[P_{\mathrm{H}_{2}}\right]^{4 n}-\frac{\left[P_{\mathrm{CH}_{4}}\right]^{n}\left[P_{\mathrm{H}_{2} \mathrm{O}}\right]^{2 n}}{\left(K_{e q}(T)\right)^{n}}\right)
$$

where, $T$ is in ${ }^{\circ} \mathrm{C}, P$ in atm, $n$ is an empirical pressure dependent constant, and $\alpha$ is a parameter which changes the kinetic dependence on $\mathrm{H}_{2} \mathrm{O}$ proposed by Falbo, et al. [34]. This kinetic expression is coherent with a Langmuire-Hinshelwood-Hougen-Watson (LHHW) mechanism, where kinetic and adsorption/desorption effects are considered in the Arrhenius term and the chemical driving force is considered within the second part of the expression. The Arrhenius term is given as:

$$
k=k_{0} \exp \left(-\frac{E_{A}}{R}\left(\frac{1}{T}-\frac{1}{T_{\text {ref }}}\right)\right)
$$

The equilibrium constant, was calculated according to Equation (3), using the empirical correlation as reported by Lunde and Kester [35]:

$$
K_{e q}(T)=\exp \left[\left(\frac{1}{1.987}\right) \cdot\left(\frac{56000}{r^{2}}+\frac{34633}{T}-16.4 \ln T+0.00557 T\right)+33.165\right]
$$

The kinetic parameters utilized are reported in Table 1. These parameters were used to validate the proposed simulation, by performing a comparison between experimental results obtained by Falbo, et al. [34] and this work's model.

Table 1. Kinetic parameters for reactor modeling. Extracted from Falbo, et al. [34].

\begin{tabular}{ccccc}
\hline $\begin{array}{c}\boldsymbol{k}_{0} \\
{\left[\mathbf{m o l} /\left(\mathbf{s} \cdot \mathbf{g}_{\text {cat }} \cdot \mathbf{a t m}\right]\right.}\end{array}$ & $\begin{array}{c}E_{\boldsymbol{A}} \\
{[\mathbf{k J} / \mathbf{m o l}]}\end{array}$ & $\begin{array}{c}n \\
{[-]}\end{array}$ & $\begin{array}{c}\alpha \\
{[1 / \mathbf{a t m}]}\end{array}$ & $\begin{array}{c}\boldsymbol{T}_{\text {ref }} \\
{\left[{ }^{\circ} \mathbf{C}\right]}\end{array}$ \\
\hline 95.43 & 75.3 & 0.152 & 0.91 & 350 \\
\hline
\end{tabular}

The reactors R-1 and R-2 were both modeled using the same kinetics; however, their dimensions and operational parameters differ due to distinct feed gas mixtures (Table 2). The length of both reactors was calculated by setting the mean residence time to $0.0005 \mathrm{~h}$ for $\mathrm{R}-1$ and $0.0007 \mathrm{~h}$ for $\mathrm{R}-2$. The mean residence time of each reactor was extracted from the patent of Solar Fuel GmbH [29]. The catalyst loading of both reactors was determined by considering a Gas Hour Space Velocity (GHSV) of 5 L (STP)/h/g cat [34]. Additionally, the pressure drop inside the reactors was calculated with the Ergun equation.

Table 2. Design and process parameters from reactors R-1 and R-2.

\begin{tabular}{lcc}
\hline Design/Process Parameter & Reactor R-1 & Reactor R-2 \\
\hline Number of tubes & 20 & 20 \\
Tube diameter $[\mathrm{m}]$ & 0.075 & 0.075 \\
Length $[\mathrm{m}]$ & 0.85 & 0.45 \\
Catalyst loading $[\mathrm{kg}]$ & 51.49 & 25.04 \\
Residence time $[\mathrm{h}]$ & 0.0005 & 0.0007 \\
Operating pressure $[\mathrm{bar}]$ & 7.00 & 7.00 \\
Gas inlet temperature, $T_{\text {in }}\left[{ }^{\circ} \mathrm{C}\right]$ & 270 & 260 \\
\hline
\end{tabular}


Since the methanation reaction is highly exothermic, heat must be removed through the complete reactor length, which presents a challenge in real isothermal operation. Improper heat removal in the reactor can lead to catalyst sintering, formation of hot spots and material stress [36]. The cooling process of the fixed-bed reactors R-1 and R-2 is performed by thermo-oil (Therminol-66 with a heat transfer coefficient of $500 \mathrm{~W} / \mathrm{m}^{2} \mathrm{~K}$ [37]) circulated in the shell side of the reactor and in counterflow to the gas mixture in the tubes. Heat exchangers HX-R1 and HX-R2, cool the thermo-oil in R-1 and R-2 to the specified inlet temperatures of $200{ }^{\circ} \mathrm{C}$ and $250{ }^{\circ} \mathrm{C}$, respectively, with the aid of cooling water. To prevent catalyst sintering, the maximum allowable temperature inside the reactors was determined to be $550{ }^{\circ} \mathrm{C}$. The pressure drop in the cooling medium is neglected in both cases.

\section{Gas Upgrading Unit}

Before injecting the obtained SNG into the local distribution gas network, some technical specifications must be verified. The product SNG must be within the acceptability boundaries specified by the DVGW G 260 standard [25]. After exiting reactor R-2 the gas mixture is cooled to $30^{\circ} \mathrm{C}$ and water is condensed and extracted in steam trap ST-2. The produced SNG is then compressed to 16 bar by a centrifugal compressor with an isentropic efficiency of $80 \%$ and a mechanical efficiency of $90 \%$. After compression, the SNG is cooled to $30{ }^{\circ} \mathrm{C}$ with the aid of cooling water. According to the results, no further purification steps are required to ensure compliance with injection standards.

\section{Thermal Integration}

To perform the thermal integration, the methodology of pinch analysis was used [38]. The target function chosen was the minimization of external heat requirement, and the minimum temperature difference $\left(\Delta T_{\min }\right)$ between hot and cold fluids, which was selected to be $20^{\circ} \mathrm{C}$. For the analyzed system it was assumed that for external cooling, water at $15{ }^{\circ} \mathrm{C}$ inlet temperature and maximum outlet temperature $25^{\circ} \mathrm{C}$ were available. Figure 2 represents the flowsheet of the pilot plant after the thermal integration was carried out. Before thermal integration, the PtSNG plant required external heating and cooling during steady-state operation.

\subsubsection{Definition of Performance Parameters}

The performance of the proposed concept was evaluated in terms of PtSNG efficiency, the fuel synthesis efficiency and the carbon conversion rate in the reactor, as defined in Table 3. Similar parameters are defined in literature $[9,12,14,39-41]$. The PtSNG efficiency determines the conversion efficiency from power to fuel and is calculated by dividing the energy content of the product SNG (LHV) by all the electric energy flows entering the system. In contrast, the fuel synthesis efficiency excludes the electrolysis part of the process and only considers the energy input from the hydrogen feedstock. The carbon conversion defines the share of carbon atoms entering the system that are converted into methane, and is a significant measure in the evaluation of maximum fuel yield or carbon dioxide potential [12].

Table 3. Definition of process performance parameters.

\begin{tabular}{lcc}
\hline Name & \multicolumn{1}{c}{ Formula } \\
\hline Power-to-SNG efficiency & $\eta_{\mathrm{PtSNG}}=\frac{\dot{m}_{\mathrm{SNG}} \cdot \mathrm{LHV}_{\mathrm{SNG}}}{P_{\mathrm{e}}}$ & $(4)$ \\
Fuel synthesis efficiency & $\eta_{\mathrm{Syn}}=\frac{\dot{m}_{\mathrm{SNG}} \cdot \dot{L H V}_{\mathrm{SNG}}}{\dot{m}_{\mathrm{H}_{2}} \cdot \mathrm{LHV}_{\mathrm{H}_{2}}}$ & $(5)$ \\
$\mathrm{CO}_{2}$ conversion in reactor & $\mathrm{X}_{\mathrm{CO}_{2}}=\frac{\mathrm{CO}_{2, \text { in }}-\mathrm{CO}_{2, \text { out }}}{\mathrm{CO}_{2, \text { in }}}$ \\
\hline
\end{tabular}

\subsection{Economic Assessment}

To calculate the net cost of production per $\mathrm{kWh}_{\mathrm{th}}$ of SNG produced, the annualized cost method was used. This approach is briefly described in this section and more in detail 
in the Supplementary Materials Sections S2-S5. The annualized cost method compares the magnitude of a capital investment in current currency with a future revenue stream by converting the capital cost into a future annual capital charge [42]. The accuracy of the cost estimation is expected to be $\pm 30 \%$ according to class three and four of the cost classification system of the Association of the Advancement of Cost Engineering (AACE) [43]. The calculation of the product's costs followed three steps:

1. Estimation of total capital and operational expenditures (CAPEX and OPEX);

2. Determination of total annualized cost (TAC);

3. Calculation of net production cost (NPC).

\subsubsection{Calculation of CAPEX}

The capital expenditure (CAPEX) or total capital investment (TCI) of a plant comprises the fixed capital investment (FCI) and working capital (WC), as defined by Peters, et al. [44] in Equation (7).

$$
\mathrm{TCI}=\mathrm{FCI}+\mathrm{WC}
$$

The FCI represents the capital necessary to design and construct the plant. While the working capital represents the money that is tied up to inventories as well as to the difference between receivable and payable accounts [42]. According to Peters, et al. [44] most chemical plants use an initial working capital of 10 to $20 \%$ of the total capital investment. In this study, the WC equals $15 \%$ of the TCI.

The FCI was calculated according to Equation (8), by multiplying the cost of each equipment $e$, by defined Lang-factors $F_{j}$, and by summing all the capital cost items. The Lang-factors $F_{j}$ are based on typical values for fluid processing plants in the chemical industry, as reported by Peters, et al. [44] and are summarized in the Supplementary Materials Section S2.

$$
\mathrm{FCI}=\sum_{k=1}^{m} \mathrm{EC}_{e}\left(1+\sum_{j=1}^{12} F_{e, j}\right)
$$

Equipment costs (EC) were evaluated by utilizing cost estimation charts reported by Ulrich and Vasudevan [37] as well as the equipment's operating parameters such as pressure and temperature. Cost estimation charts provide values for the base state equipment cost, which considers a base material (usually carbon steel), and arise from exponential size-capacity relationships described as:

$$
C_{v, r}^{0}=C_{u, r}^{0}\left(\frac{v}{u}\right)^{a},
$$

where $C_{v, r}^{0}$ is the purchase price of the equipment in question, which has a capacity $v$ in year $r$ and $C_{u, r}^{0}$ is the purchase price of the same type of equipment but with capacity $u$. The scaling factor is represented by the parameter $a$. Equipment sizing methodology and estimations are detailed in the Supplementary Materials Section S3.

To account for inflation, the Chemical Engineering Plant Cost Index (CEPCI) [45] was used to adjust prices to the chosen reference year, as shown in Equation (10). In this study, the reference year is 2018 and equipment prices given in U.S. Dollar (\$) basis were first converted to Euro $(€)$ utilizing the average exchange rate of 2018 which is equal to $0.8476 € / \$[46]$.

$$
C_{v, 2018, \epsilon}^{0}=C_{v, 2004, \$}^{0}\left(\frac{\mathrm{CEPCI}_{2018}}{\mathrm{CEPCI}_{2004}}\right) \cdot 0.8476
$$

\subsubsection{Calculation of OPEX}

Operation costs can be broken down into variable costs of production (direct OPEX) and fixed costs of production (indirect OPEX) [42]. Variable costs of production are proportional to the plant output and include raw materials, utilities, and consumables (e.g., 
catalyst). The fixed costs of production are expenses that are incurred regardless of the production rate such as maintenance, taxes, insurance, and overheads.

Variable costs were calculated based on results from the process simulation and market prices reported in Table 4. The price of utilities and raw materials were obtained from the German BEniVer "Begleitforschung Energiewende im Verkehr" initiative [47], which aims to standardize the boundary conditions of electricity-based fuels' techno-economic assessments. The electricity price of $50 € / \mathrm{MWh}$ does not include duties, such as the EEG levy and grid access tax. The $\mathrm{CO}_{2}$ supply price was determined by considering the $\mathrm{CO}_{2}$ origin at a biomethane upgrading plant. Analogous to Viebahn, et al. [48], the separation costs are set to zero since $\mathrm{CO}_{2}$ is an unwanted by-product of biogas treatment. Nevertheless, compression and transportation costs must be considered. Brynolf, et al. [39] and $\mathrm{Fu}$, et al. [49] report on $\mathrm{CO}_{2}$ supply from high purity sources and suggest a $\mathrm{CO}_{2}$ cost of $20 € / \mathrm{t}$, including compression and transportation up to $60 \mathrm{~km}$. Hence, this value was utilized for the Reference case NPC estimation. Moreover, the catalyst price was obtained via a direct quotation from the commercial manufacturer Riogen, and a complete catalyst replacement every two years was assumed.

Table 4. Reference case market price for variable costs items.

\begin{tabular}{lcc}
\hline Variable Cost Item & \multicolumn{3}{c}{ Market Price } \\
\hline Electricity & 50 & $€ / \mathrm{MWh}$ \\
Cooling water & 0 & $€ / \mathrm{t}$ \\
Distilled Water & 1 & $€ / \mathrm{t}$ \\
$\mathrm{CO}_{2}$ & 20 & $€ / \mathrm{t}$ \\
0.5 wt. $\% \mathrm{Ru} / \mathrm{Al}_{2} \mathrm{O}_{3}$ Catalyst & 1288 & $€ / \mathrm{kg}$ \\
\hline
\end{tabular}

Fixed production costs were estimated by utilizing typical valuations based on historical data from the chemical industry [44]. Fixed cost production items include insurance and taxes, operating labor, maintenance, operating supplies, administrative costs, and plant overhead costs. To estimate a fixed production cost item $y$, a corresponding ratio factor $W_{y}$ was multiplied by a defined basis $B_{y}$. Used ratio factors $W_{y}$ were obtained from Peters, et al. [44] and are detailed in the Supplementary Materials Section S4. The annual costs for operating labor (OL) were determined based on typical labor requirements for process equipment, as suggested by Ulrich and Vasudevan [37] and the average specific labor costs in the German industry. The cost of an employee in the chemical industry in Germany was assumed to be $66,693 €$ per year, including non-wage labor costs [26]. Lastly, all fixed production costs items were summed in order to estimate the total indirect operational expenses.

\subsubsection{Total Annualized Cost}

To determine the total annualized cost of production (TAC) the annual capital charge (ACC) is added to the total operating costs as per Equation (11). The annual capital charge (ACC) is in turn calculated by multiplying the annual capital charge ratio (ACCR), by the fixed capital investment Equation (12).

$$
\mathrm{TAC}=\mathrm{ACC}+\text { direct OPEX }+ \text { indirect OPEX }
$$

$$
\mathrm{ACC}=\mathrm{ACCR} \cdot \mathrm{FCI}
$$

Considering the amortization of a capital investment, the annuity $(A)$ is the regular annual payment that must be made to generate the same amount of money over $n$ years, as will be earned by investing $P$ at interest rate $i$ for $n$ years [42]. The capital charge ratio (ACCR) can be calculated as shown in Equation (13).

$$
\mathrm{ACCR}=\frac{A}{P}=\frac{\left[i(1+i)^{n}\right]}{\left[(1+i)^{n}-1\right]}
$$




\subsubsection{Net Production Cost}

The net production cost (NPC) was calculated according to Equation (14):

$$
C_{\mathrm{SNG}}=\frac{\mathrm{TAC}}{\dot{m}_{\mathrm{SNG}} \cdot \mathrm{HHV}_{\mathrm{SNG}} \cdot h}
$$

The mass flow rate $\left(\dot{m}_{\mathrm{SNG}}\right)$ and the higher heating value $\left(\mathrm{HHV}_{\mathrm{SNG}}\right)$ of the product SNG were extracted from the process simulation. The annual operational hours of the plant, $h$, were set to $8000 \mathrm{~h}$ for the Reference case. A detailed NPC calculation for the Reference case is provided in the Supplementary Materials Section S5. In economic calculations $\mathrm{HHV}_{\mathrm{SNG}}$ was used, since natural gas is priced on this basis [50]. Nevertheless, for technical calculations, since heat balances are involved, SNG's lower heating value (LHV) was employed for more accurate results.

\subsubsection{Scenario Definition}

To obtain an overview of how the SNG net production cost may vary according to the business model of the PtSNG plant, different scenarios were developed and evaluated. The characteristics of the operation of the $1 \mathrm{MW}_{\mathrm{el}}$ PtSNG plant in each of the five scenarios is detailed below.

1. Taxed Ref 2020: Previously described Reference case but considering EEG taxation;

2. AEL 2020: Analogous to the Reference case but operation with an alkaline electrolyzer;

3. Wind 2020: The pilot plant only utilizes offshore wind energy for hydrogen production in 2020, assuming a direct coupling between the offshore wind turbine and the PtSNG plant. Standby consumption from electrolyzer is assumed to be $1 \%$;

4. Surplus 2030: The PtSNG plant only operates with surplus electricity coming from renewable generation in Germany in 2030. Electricity costs during surplus hours equal zero, as the plant consumes electricity that would otherwise be curtailed. At all other times the electrolyzer is shut down and standby operating mode is not considered;

5. Cement-CC 2030: The PtSNG plant operates with electricity from the grid in 2030 and benefits from carbon trading. A cement company is assumed to pay the pilot plant to consume its $\mathrm{CO}_{2}$.

Table 5 summarizes the framework conditions assumed in each scenario. The Reference case was also included to enhance the comparability of results; however in this instance the EEG levy was incorporated.

Table 5. Framework conditions for each scenario.

\begin{tabular}{|c|c|c|c|c|c|}
\hline & Taxed Ref. 2020 & $\begin{array}{l}\text { AEL } \\
2020\end{array}$ & $\begin{array}{l}\text { Wind } \\
2020\end{array}$ & $\underset{2030}{\text { Surplus }}$ & Cement-CC 2030 \\
\hline Electrolyzer & PEM & Alkaline & PEM & PEM & PEM \\
\hline $\begin{array}{l}\text { Annual full-load } \\
\text { hours }\end{array}$ & 8000 & 8000 & $3800[51]$ & 205 [52] & 8000 \\
\hline Electricity source & German grid $^{b}$ & German grid $^{b}$ & Offshore wind & Offshore wind & German grid (2030) ${ }^{c}$ \\
\hline $\begin{array}{l}\text { Electricity cost } \\
(€ / \mathrm{MWh})\end{array}$ & 50 & 50 & $102[53]$ & 0 & 58 \\
\hline EEG levy (€/MWh) & $67[54]$ & $67[54]$ & 0 & 0 & 35 [54] \\
\hline $\mathrm{CO}_{2}$ source & $\begin{array}{l}\text { Biomethane } \\
\text { plant }\end{array}$ & $\begin{array}{l}\text { Biomethane } \\
\text { plant }\end{array}$ & $\begin{array}{l}\text { Biomethane } \\
\text { plant }\end{array}$ & $\begin{array}{l}\text { Biomethane } \\
\text { plant }\end{array}$ & $\begin{array}{l}\text { Cement } \\
\text { plant }\end{array}$ \\
\hline $\mathrm{CO}_{2} \cos t(€ / t)$ & 20 & 20 & 20 & 20 & $5^{a}$ \\
\hline $\mathrm{CO}_{2}$ credits $(€ / \mathrm{t})$ & - & - & - & - & $55[55]$ \\
\hline Plant operators & 3 & 3 & 2 & 1 & 3 \\
\hline
\end{tabular}

Mid-term (2030) scenarios consider electrolyzer cost reduction due to technological developments and market effects. However, methanation is assumed to be an already mature technology in 2020, for which no future (2030) cost reductions will occur. Furthermore, 
to make the scenarios more realistic, taxes associated with electricity consumption and gas network utilization were reviewed. In Germany, Power-to-Gas plants are exempt from electricity grid fees and electricity tax upon application ( $\$ 9$ StromStG). Nevertheless, the EEG levy is still payable. The SNG generated in a PtG plant is also exempt from the gas network charges (§118 EnWG).

\subsection{Environmental Assessment}

An attributional life cycle analysis (LCA) is performed to assess the environmental impacts of the defined SNG scenarios in comparison to conventional natural gas supply. The LCA aims to identify operational conditions resulting in reduced greenhouse gas emissions and by this means also to point to critical components or flows, e.g., source of $\mathrm{CO}_{2}$ or electricity. The system boundary is defined as cradle-to-gate with SNG as a functional unit based on its energy content using the LHV as depicted in Figure 1. To solve any multifunctionality problem, the substitution approach is applied for the $\mathrm{CO}_{2}$ sources, whereas by-products such as $\mathrm{O}_{2}$ and surplus heat are neglected to be consistent with the techno-economic analysis. Life cycle inventory data are based on the process simulation of this paper (see Supplementary Materials Section S8) and the ecoinvent 3.7.1 cut-off database [56] with, wherever possible, a focus on Germany as geographic area and a temporal coverage of 2020. The ILCD Midpoint method yields the environmental impacts for each scenario considering the climate change category. In addition, the categories acidification, freshwater eutrophication, human toxicity (cancer and non-cancer effects), ionizing radiation, marine eutrophication, ozone depletion, photochemical ozone formation and terrestrial eutrophication are discussed. A future electricity grid mix for Germany in 2030 is defined as in the Revolution Scenario in EWI Energy Research and Scenarios [57] with details provided in the Supplementary Materials Section S8. The different $\mathrm{CO}_{2}$ and $\mathrm{H}_{2}$ sources for all scenarios are described in Table 6.

Table 6. Boundary conditions used for the life cycle analysis.

\begin{tabular}{|c|c|c|c|}
\hline Source & Process & Description & Reference \\
\hline & Biomethane & Burden-free $\mathrm{CO}_{2}$ & {$[56]$} \\
\hline $\mathrm{CO}_{2}$ & Cement plant & $\begin{array}{l}\text { Electricity: } 0.103 \mathrm{kWh} / \mathrm{kg} \mathrm{CO}_{2} \text { captured } \\
\text { Steam: } 1.03 \mathrm{kWh} / \mathrm{kg} \mathrm{CO} 2 \text { captured } \\
\text { MEA: } 0.013 \mathrm{~kg} \mathrm{MEA} / \mathrm{kg} \mathrm{CO}_{2} \text { captured } \\
\text { Capture efficiency: } 85 \% \\
\text { Emissions are divided between cement and } \mathrm{CO}_{2} \text { production by } \\
\text { applying substitution }\end{array}$ & $\begin{array}{l}{[58]} \\
{[58]} \\
{[56]} \\
\\
{[58]}\end{array}$ \\
\hline
\end{tabular}
applying substitution

Alkaline electrolyzer stack inventory and balance of plant inventory

AEL Electricity: $58.27 \mathrm{kWh} / \mathrm{kg} \mathrm{H}_{2}$ Source according to scenario

Process simulation Water, deionised: $8.94 \mathrm{~kg} \mathrm{H}_{2} \mathrm{O} / \mathrm{kg} \mathrm{H}_{2}$

Process simulation

$\mathrm{H}_{2}$

Balance of plant inventory

BOP lifetime: 20 years

PEM stack inventory for 2017

PEM Stack: $1 \mathrm{MW}$;

Stack lifetime: 7 years

[60]

Electricity: $55 \mathrm{kWh} / \mathrm{kg} \mathrm{H}_{2}$

Source according to scenario

[60]

Water, deionised: $8.94 \mathrm{~kg} \mathrm{H}_{2} \mathrm{O} / \mathrm{kg} \mathrm{H}_{2}$

Process simulation


Table 6. Cont.

\begin{tabular}{|c|c|c|c|}
\hline Source & Process & Description & Reference \\
\hline & \multirow{7}{*}{ PEM (2030) } & Balance of plant inventory & \multirow{2}{*}{ [60] } \\
\hline & & BOP lifetime: 20 years & \\
\hline & & PEM stack inventory for 'near future' & \multirow{2}{*}{ [60] } \\
\hline & & Stack 1 MW; Stack lifetime: 10 years & \\
\hline & & Electricity: $55 \mathrm{kWh} / \mathrm{kg} \mathrm{H}$ & \multirow{2}{*}{ [60] } \\
\hline & & Source according to scenario & \\
\hline & & Water, deionised: $8.94 \mathrm{~kg} \mathrm{H}_{2} \mathrm{O} / \mathrm{kg} \mathrm{H}_{2}$ & Process simulation \\
\hline
\end{tabular}

\section{Results and Discussion}

\subsection{Technical}

The simulation yields around $34 \mathrm{~kg} / \mathrm{h}$ of synthetic natural gas and shows a plant capacity of $0.46 \mathrm{MW}_{\mathrm{SNG}}$, considering SNG's LHV. Characteristics of the product SNG and gas standards required by the DVGW for injection in the gas grid are compared in Table 7.

Table 7. Comparison of produced SNG and German gas injection requirements. Values according to the DVGW G 260 standard [25].

\begin{tabular}{lcc}
\hline Characteristic & Required Gas Value & SNG Value \\
\hline Wobbe Index $\left[\mathrm{kWh}_{\mathrm{th}} / \mathrm{m}^{3}\right]$ & $13.6-15.7$ & 13.7 \\
Calorific Value $\left[\mathrm{kWh} \mathrm{th}_{\mathrm{th}} / \mathrm{m}^{3}\right]$ & $8.4-13.1$ & $10.1(\mathrm{HHV})$ \\
& $<50$ in grids $>10$ bar & $9.1(\mathrm{LHV})$ \\
Water content $\left[\mathrm{mg} / \mathrm{m}^{3}\right]$ & $<10$ bar & 40 \\
Hydrogen content $[\mathrm{vol} \%]$ & $<2$ & 4 \\
Carbon dioxide content $[\mathrm{vol} \%]$ & $\begin{array}{c}\text { in exceptional cases up to }<10 \\
\text { in H-gas grids }<10\end{array}$ & 1 \\
\hline
\end{tabular}

After two methanation stages, the produced SNG has a 94.5\% methane content and complies with all characteristics for injection in the natural gas network.

The pilot plant's main material flows, energy flows and process performance parameters are summarized in Table 8 . Approximately $34 \mathrm{~kg} / \mathrm{h}\left(3.38 \mathrm{~m}^{3} / \mathrm{h}\right)$ of synthetic natural gas are produced from $92 \mathrm{~kg} / \mathrm{h}$ of $\mathrm{CO}_{2}$ and $150 \mathrm{l} / \mathrm{h}$ of distilled water. The by-products oxygen $\left(17.53 \mathrm{~m}^{3} / \mathrm{h}\right)$ and district/industrial heat $\left(1.55 \mathrm{~kJ} / \mathrm{kg}_{\mathrm{SNG}}\right.$ or $\left.0.525 \mathrm{MJ}\right)$ are also available. Since the methanation process is highly exothermic, there is significant waste heat potential integration. Even after the heat integration via Pinch analysis was performed, $0.15 \mathrm{MJ}$ of heat at temperatures $114-338^{\circ} \mathrm{C}$ are available from the heat exchangers. Additional $0.38 \mathrm{MJ}$ waste heat from the PEM electrolyzer at $80{ }^{\circ} \mathrm{C}$ are also available for further utilization. The excess produced heat could be integrated into other processes and/or used for district heating; nevertheless, such waste heat recuperation is not considered in the present work.

Table 8. PtSNG plant material flows, energy flows and performance parameters with a $1 \mathrm{MW}_{\mathrm{el}}$ electrolyzer.

\begin{tabular}{lc}
\hline Parameter & Value \\
\hline Material flows $[\mathrm{kg} / \mathrm{h}]$ & \\
$\mathrm{CO}_{2}$ & 91.96 \\
Distilled water for electrolysis & 150.58 \\
Cooling water & 5788.57 \\
Oxygen & 133.73 \\
$\mathrm{SNG}, \dot{\mathrm{m}}_{\mathrm{SNG}}$ & 33.83 \\
\hline
\end{tabular}


Table 8. Cont.

\begin{tabular}{lc}
\hline Parameter & Value \\
\hline Energy flows & \\
Electricity, $\mathrm{P}_{\mathrm{el}}[\mathrm{MW}]$ & 1.002 \\
Waste heat [MJ] & 0.525 \\
SNG output [MW] & $0.513(\mathrm{HHV}) ; 0.461(\mathrm{LHV})$ \\
Performance parameters & $\mathrm{R}-1: 96 \% ; \mathrm{R}-2: 76 \%$ \\
$\mathrm{CO}_{2}$ conversion in reactor & $46 \%$ \\
Power-to-SNG efficiency & $82 \%$ \\
Fuel synthesis efficiency & 8 \\
\hline
\end{tabular}

The $\mathrm{CO}_{2}$ conversion in $\mathrm{R}-1$ matches with the value given in the patent from Solar Fuel $\mathrm{GmbH}$ [29] (96\% compared to $95 \%$ ), while the $\mathrm{CO}_{2}$ conversion in $\mathrm{R}-2$ is lower, at $76 \%$ compared to the reported $90 \%$. This lower $\mathrm{CO}_{2}$ conversion in the second reactor is due to the presence of water, which inhibits the Sabatier reaction. Potential solutions include adding another stream trap after ST-1 and incorporating a recycle loop to reactor R-2 to reduce the presence of water in the inlet stream.

The plant's Power-to-SNG efficiency is $46 \%$, implying that less than half of the input power is converted into fuel. The value obtained in this work lies in the upper range of published values (30-50\%) collected through a literature review by Brynolf, et al. [39]. The same authors found fuel synthesis efficiencies in literature to be between $70 \%$ and $83 \%$, while this work's fuel synthesis efficiency is $82 \%$. Overall, the results from the Aspen Plus ${ }^{\circledR}$ simulation showed that the proposed PtSNG pilot plant concept is technically achievable with good performance, and comparable to literature values.

\subsection{Economic}

First, the equipment costs are presented based on the technical parameters defined in Section 2.1.2 and the economic approaches for the CAPEX defined in Section 2.2.1. Using the defined parameters for the reference case, the total capital investment for a $1 \mathrm{MW}_{\mathrm{el}}$ PtSNG plant was estimated to be $4.86 \mathrm{M} €$. The full results of equipment costs can be found in the Supplementary Materials Section S3. As shown in Figure 5, more than half of the capital investments are incurred by expenses associated with the plant equipment (53\%) and almost a quarter by indirect capital costs $(26 \%)$. The most significant expenditure concerns the PEM electrolyzer, which represents $83 \%$ of the total equipment cost. The second largest equipment cost component is the gas compressor, which equals $8 \%$ of the total equipment cost.

The annual operational expenses amount to $843 \mathrm{k} € / \mathrm{y}$, considering the aforementioned Reference case, and their cost distribution is illustrated in Figure 6. The cost of electricity used for electrolysis is significant, representing $42 \%(400 \mathrm{k} € / \mathrm{y})$ of the total operational expenses. Both electricity and cooling water are used in the plant, and since the cooling water cost has been neglected, electricity is the only expense associated with utilities. Unexpectedly, $\mathrm{CO}_{2}$ cost has a minor impact on the overall OPEX calculation, amounting to $14 \mathrm{k} € / \mathrm{y}$. Similarly, raw materials and supplies have a limited effect on the final SNG cost. The largest cost component is the indirect OPEX (operating labor (OL) plus indirect operational costs, in Figure 6), which represents 55\% of the total OPEX and 10\% of the FCI. The indirect operational expenditures' value is highly influenced by the method utilized for cost estimation. The largest indirect operational cost is the OL cost which amounts to $200 \mathrm{k} € / \mathrm{y}$ and $21 \%$ of the total operational costs. The Reference case considers plant operation at $100 \%$ capacity factor, and therefore three work shifts are required. For each shift only one operator is necessary, on account of a highly automated plant integrated in a larger chemical complex. 


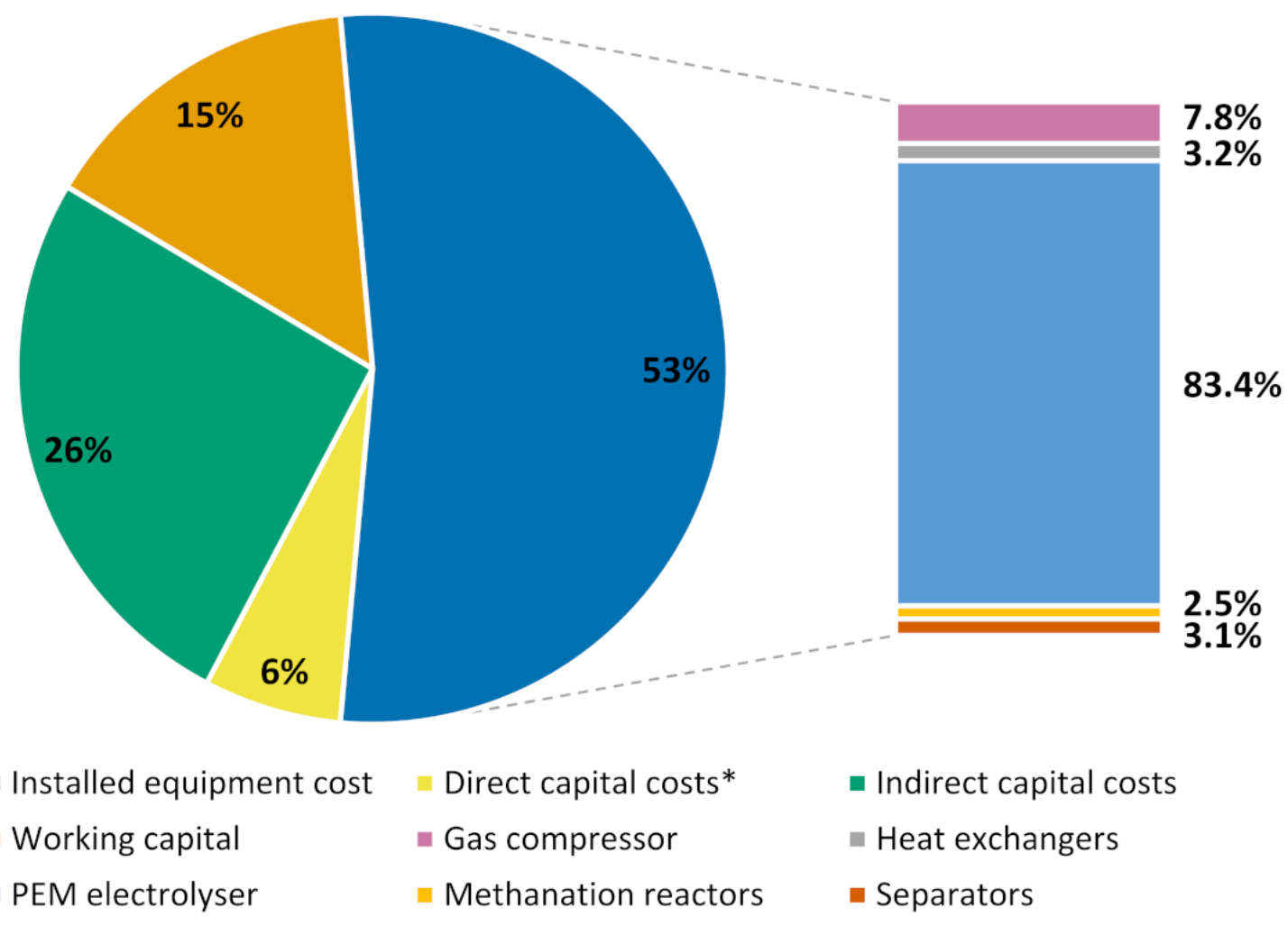

Figure 5. Total capital investment distribution for a $1 \mathrm{MW}$ PtSNG plant. Installed equipment cost includes equipment cost, installation, instrumentation, piping and power supply. * Direct capital costs exclude installed equipment cost, but consider building, yard improvements and service facilities. Indirect capital costs comprise engineering and supervision, construction and legal expenses, contractor's fee and contingency.

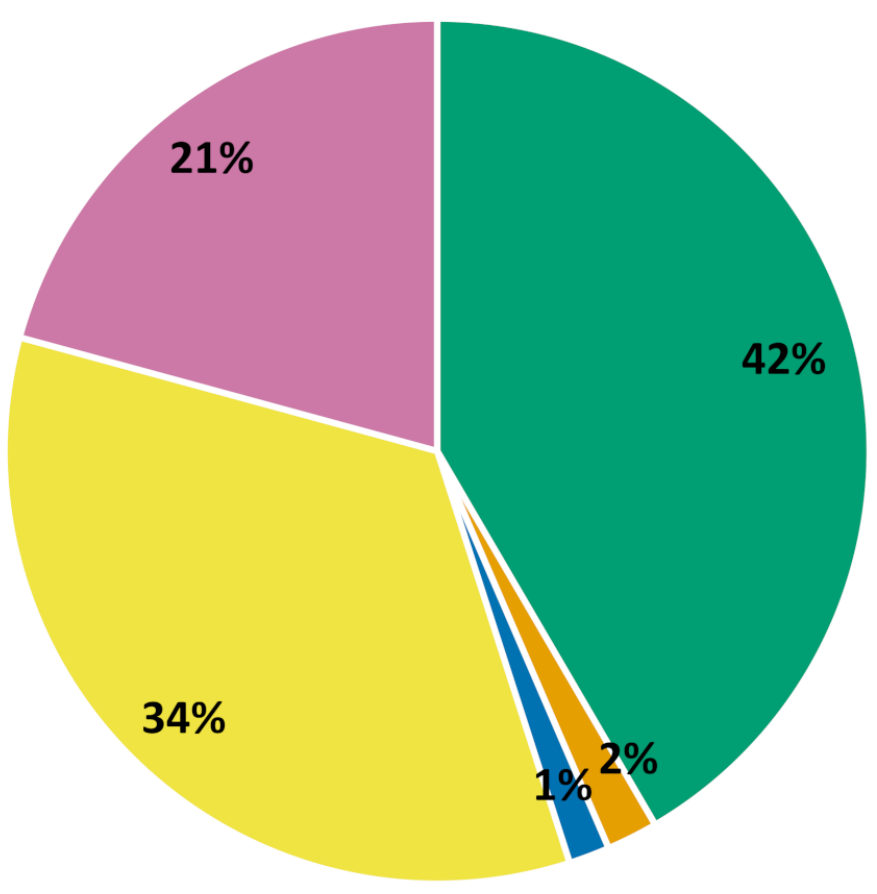

- Electricity

- Raw materials and supplies*

- $\mathrm{CO}_{2}$

- Indirect operational costs+

- Operating labour

Figure 6. Operational expenses distribution for the Reference case. * Raw materials and supplies include distilled water and catalyst; however, they exclude $\mathrm{CO}_{2}$ supply. + All indirect operational costs, except for operating labour are included. 
The SNG net production cost is estimated at $0.32 € / \mathrm{kWh}_{\text {th }}$ for the Reference case, without considering taxes. This number rises to $0.45 € / \mathrm{kWh}_{\text {th }}$, once the EEG levy is considered in the Taxed Ref 2020 scenario (Figure 7). This significant cost increase occurs as a result of the large electricity price, which with the addition of the EEG levy rises from $50 € / \mathrm{MWh}$ to $117 € / \mathrm{MWh}(134 \%$ increase). The large contribution of the CAPEX to the SNG NPC exhibits a capital-intensive manufacturing process, where the electrolyzer is a significant player. Furthermore, the electricity used for hydrogen production represents a significant amount $(22 \%)$ of the SNG cost. Other operational costs represent the remaining $31 \%$ of the SNG net production cost. When considering the sale of by-products oxygen and heat at $35 € / \mathrm{t}$ and $26 € / M W h$, respectively, a SNG NPC reduction of $0.03 € / \mathrm{kWh}_{\mathrm{th}}$ is achieved. Rationale for the pricing of the by-products can be found in the Supplementary Materials Section S5.

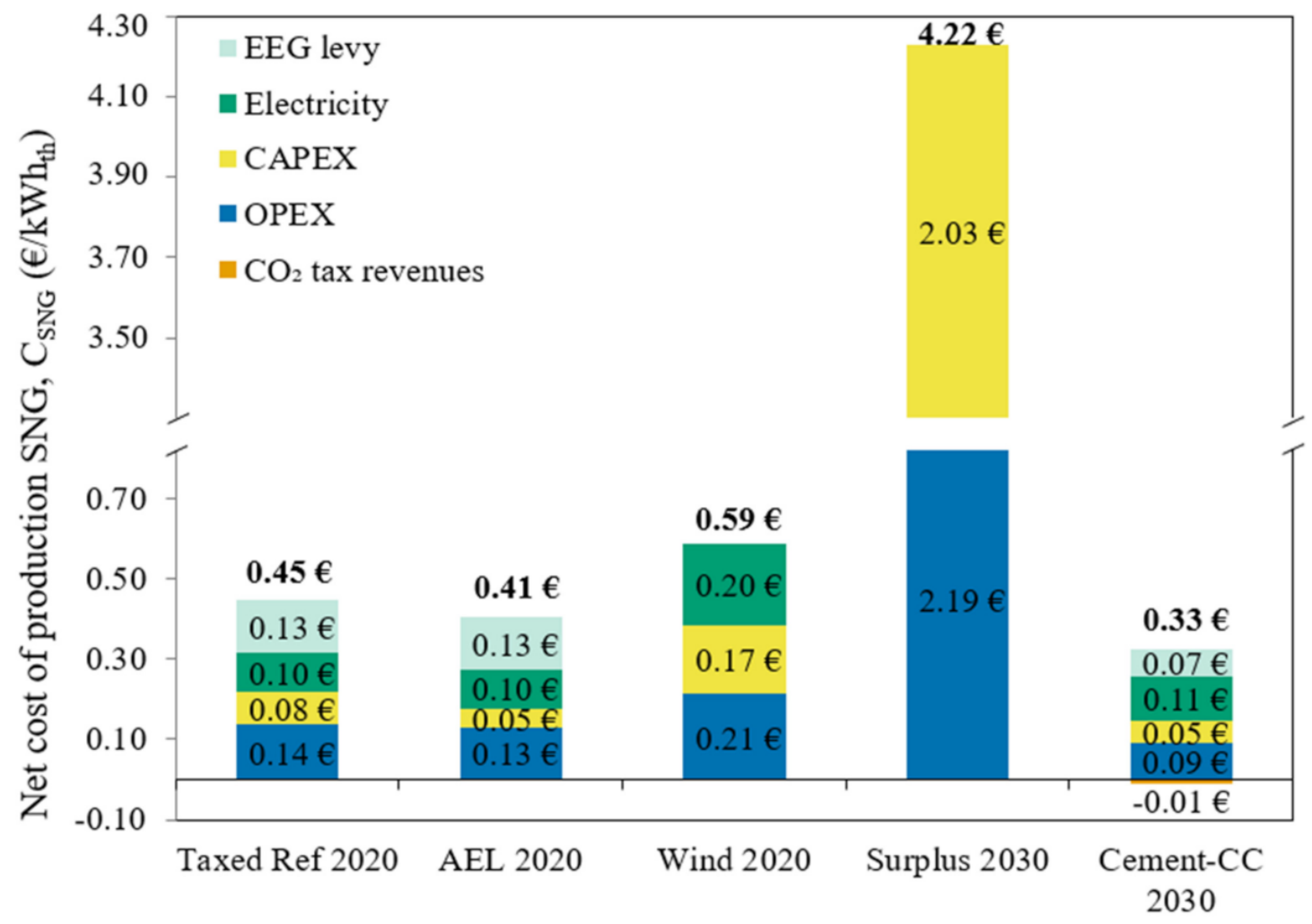

Figure 7. SNG net cost of production per scenario.

Scenario AEL 2020 achieves a SNG NPC of $0.41 € / \mathrm{kWh}_{\mathrm{th}}$, which represents a $10 \%$ cost saving compared to the Taxed Ref 2020. This cost reduction is entirely attributed to the capital cost decrease, which in turn is associated with the replacement of the PEM electrolyzer with an alkaline one. The capital cost of the alkaline electrolyzer is $70 \%$ less than that of the PEM electrolyzer, but its maintenance cost, including stack replacement, is 36\% higher than of the PEM electrolyzer. Considering this, and the fact that electricity supply cost represents 56\% of AEL 2020's SNG NPC, only a limited cost reduction is achieved by replacing the PEM electrolyzer with an alkaline one.

Scenario Wind 2020 employs only offshore wind power to generate SNG at $0.59 € / \mathrm{kWh}_{\text {th }}$ representing a 31\% increase from the Taxed Ref 2020. Electricity in this scenario is provided at $102 € / \mathrm{MWh}$, connoting a 13\% reduction in the cost of electricity supply compared to the Taxed Ref 2020 scenario (considering $117 € / M W h$ ). It should be mentioned that no EEG is paid in Scenario Wind 2020, since the electricity comes from renewable generation. The increase of the SNG NPC in the Wind 2020 scenario is therefore attributed to the reduction in annual full-load operating hours, which are limited to $3800 \mathrm{~h}$.

The Surplus 2030 Scenario, which only utilizes surplus electricity in 2030 to generate $\mathrm{SNG}$, has a fuel cost of $4.22 € / \mathrm{kWh}_{\mathrm{th}}$, which is approximately nine times more expensive 
than the Taxed Ref 2020 Scenario. This dramatic SNG cost increase is due to the extremely low annual full-load operating hours $(203 \mathrm{~h})$, which are not sufficient to amortize either the CAPEX or the fixed OPEX.

Lastly, the Cement-CC 2030 scenario produces SNG at an NPC of $0.33 € / \mathrm{kWh}_{\mathrm{th}}$ in 2030 , considering carbon trading and electricity supplied by the grid. This fuel cost is $27 \%$ lower than the SNG NPC of the Taxed Ref 2020 and can be attributed to the consideration of a price reduction of the electrolyzer, electricity cost decrease in 2030, and carbon trading. Nevertheless, it is visible that carbon trading only has a small impact on the overall NPC of SNG, since the additional $\mathrm{CO}_{2}$ revenue only contributes with a minor saving of $1 €$-cent $/ \mathrm{kWh}_{\text {th }}(3 \%)$.

The market price of natural gas is used as a reference for contextualizing SNG cost in the current economic environment in Germany. In 2021 the estimated SNG cost is approximately five times higher than the price private customers pay for natural gas $\left(0.06 € / \mathrm{kWh}_{\mathrm{th}}\right)$ and eight times higher than the price for industrial customers $\left(0.04 € / \mathrm{kWh}_{\mathrm{th}}\right)$; for further information see Supplementary Materials Section S7. If compared to the 2021 cross-border natural gas price, which excludes taxes, SNG is almost 18 times more expensive than natural gas $\left(0.02 € / \mathrm{kWh}_{\mathrm{th}}\right)$. In 2030 , natural gas price is expected to increase by $35 \%$ leading to a mean price of $0.06-0.8 € / \mathrm{kWh}$ for household consumers [61]. If compared to the best performing scenario Cement-CC 2030, natural gas in 2030 will be four to eight times more economical than SNG. Even additional $\mathrm{CO}_{2}$-taxes do not have a significant effect, as will be discussed at the end of Section 3.2.

An alternative to make the produced SNG more economically competitive could be to offer it in the mobility sector, which has a higher market price (0.08 €/kWh in 2019) [62]. Nevertheless, additional compression and purification of the SNG would be necessary for suitable use in the automotive industry. Since electricity costs and annual operating hours are crucial for the economic performance of the PtSNG plant, an optimization of these parameters can be undertaken. For example, when assuming that the plant is connected to the electricity grid and will always be operated at times with the cheapest electricity prices, a limit to the electricity price can be set. Store \& Go [63] calculated separate average electricity price for each full-load hour in 2030. These data were used to find the optimum combination of price limit and annual full-load operating hours, which resulted in a price limit of $73.3 € / \mathrm{MWh}$ (36 €/MWh electricity mean price), $6000 \mathrm{~h} / \mathrm{y}$ and a SNG cost of $0.30 € / \mathrm{kWh}$. Thus, portraying the importance of achieving the highest possible number of operating hours while maintaining a relatively low electricity price and labour cost. Furthermore, when we consider a long-term scenario in 2050, where Direct Air Capture (DAC) and renewable electricity would be employed, the electricity would have to be provided for a very low cost and maximum full-load operating hours in order to be able to amortize the additional capital investment of the DAC system.

If in the future, $\mathrm{CO}_{2}$ emissions from natural gas combustion are subject to taxation, natural gas cost will rise, and synthetic fuels will become economically competitive. This assumes that customers will pay the market price of natural gas plus a tax for the $\mathrm{CO}_{2}$ emissions associated with the fuel combustion. However, due to the "green" nature of SNG, it will be exempt from said $\mathrm{CO}_{2}$ tax. As a result, in the Ref scenario every ton of released $\mathrm{CO}_{2}$ will have to be taxed between $2159 €$ and $2374 €$, to make SNG price competitive depending on the natural gas tariff used. Considering all the investigated scenarios a minimum $\mathrm{CO}_{2}$ tax of $1442 € / \mathrm{t}$ will be required for SNG's and natural gas' price to be equal. The current $\mathrm{CO}_{2}$ price is $25 € / t$ and it is estimated to rise to $55 € / t$ by 2030 [54,55]. It appears, therefore, that taxing the $\mathrm{CO}_{2}$ emitted from natural gas combustion is an unviable way to make SNG economically competitive. The calculated capital, operational and SNG net production costs were compared to values published in eleven studies analyzing Power-to-SNG plants [8,10,14,15,18,26,41,64-67]. Figure 8 illustrates the values collected from the literature review and the ones calculated in this work. A detailed compilation of the expenses and assumptions from the aforementioned studies is provided in the Supplementary Materials Section S6. 


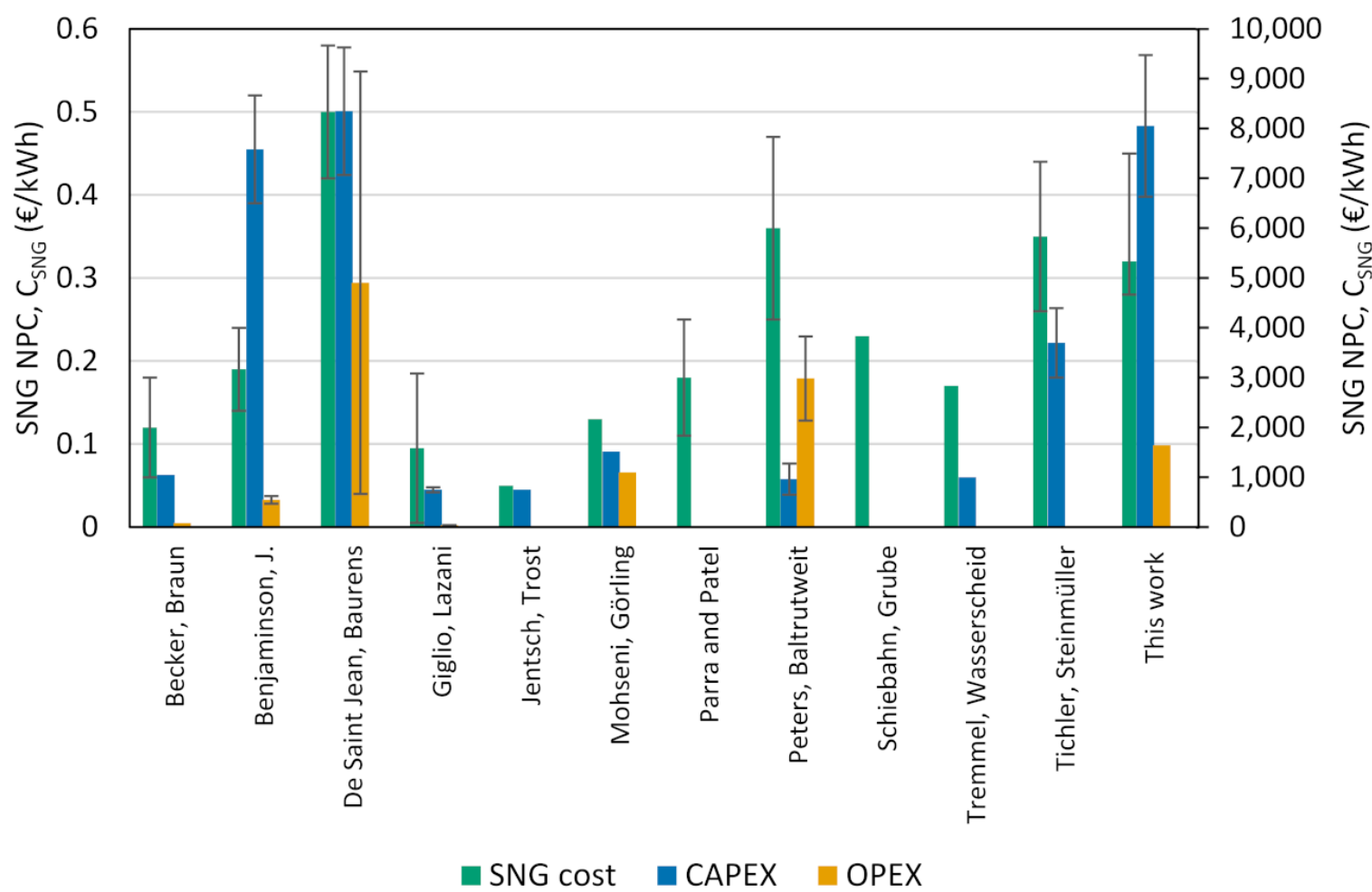

Figure 8. Literature comparison SNG, CAPEX and OPEX. Expenses not shown in the figure could not be calculated in $€ / \mathrm{kW}$ from the available information. For further information refer to Supplementary Materials Section S6. Examined works include Becker, et al. [68], Benjaminsson, et al. [8], De Saint Jean, et al. [10], Giglio, et al. [64], Jentsch, et al. [65], Mohseni, et al. [66], Parra and Patel [18], Schiebahn, et al. [15] Peters, et al. [26], Tremel, et al. [14], Tichler, et al. [67].

Reviewed capital expenses ranged from $590 € / \mathrm{kW}_{\mathrm{SNG}}$ to $9630 € / \mathrm{kW}_{\mathrm{SNG}}$. Low CAPEX results either did not account for hydrogen production or had a large plant capacity (>10 $\mathrm{MW}_{\mathrm{SNG}}$ ) [41,65]. In contrast, higher CAPEX costs of 7070-9630 $€ / \mathrm{kW}_{\mathrm{SNG}}$ mostly considered smaller plants of $0.5 \mathrm{MW}_{\mathrm{SNG}}$ capacity $[8,10]$. Of the eleven reviewed analyses, nine neglected the working capital as part of capital investment. The two studies that included the WC, estimated it at $15 \%$ of the FCI $[26,41]$. The estimated capital investment in this study is $9473 € / \mathrm{kW}_{\text {th }}$ and, when neglecting the WC, the capital investment amounts to $8052 € / \mathrm{kW}_{\text {th }}$. This CAPEX value lies in the upper range within literature ranges and coincides with values obtained with a small plant capacity. Differences among published values can be attributed to the detail employed in the calculation method and economies of scale.

Literature operating expenses range from $38 € / \mathrm{kW}_{\mathrm{SNG}}$ to $9144 € / \mathrm{kW}_{\mathrm{SNG}}$, with an average value of $1812 € / \mathrm{kW}_{\mathrm{SNG}}$. Operation and maintenance (O\&M) expenses were most commonly calculated as $3-4 \%$ of CAPEX $[8,10,14,15,18,65,67]$. In this study, the operational costs amount to $1642 € / \mathrm{kW}_{\text {th }}$ and O\&M expenses to $11 \%$ of the CAPEX. This cost difference is connected to the conservative cost estimation method used in this work.

SNG production costs in literature range from $0.05 € / \mathrm{kWh}_{\text {th }}$ to $0.58 € / \mathrm{kWh}_{\text {th }}$. Higher fuel production costs of $0.42-0.58 € / \mathrm{kWh}_{\text {th }}$ assume low annual operating hours $(4500 \mathrm{~h})$ and small plant capacity $\left(1 \mathrm{MW}_{\mathrm{el}}\right)$ [10]. Very economical SNG costs either do not consider water electrolysis or have a large plant capacity (>10 $\left.\mathrm{MW}_{\mathrm{SNG}}\right)$ [41,65]. Mohseni, et al. [66] consider a plant with 1.2 $\mathrm{MW}_{\mathrm{SNG}}$ capacity, which accounts for revenues from by-products (oxygen: $55 € / \mathrm{t}$ and heat: $31 € / \mathrm{MWh}$ ) and leads to a break-even SNG price of $0.12 € / \mathrm{kWh}$. This SNG price is the lowest study average cost found in literature and is associated with operational expenses amounting to $5 \%$ of the capital investment and also with low capital costs, which consider a specific alkaline electrolyzer equipment cost of $261 € / \mathrm{kW}_{\mathrm{el}}$ in comparison to the present work with an equipment cost of $700 € / \mathrm{kW}_{\mathrm{el}}$ [28]. In their work 
Giglio, et al. [64] accounted for a PtSNG plant operating $8000 \mathrm{~h}$ with and h $10 \mathrm{MW}_{\mathrm{el}}$ SOEC electrolyzer and varying electricity price. At an electricity price of $50 € / \mathrm{MWh}$ the SNG cost amounted to $0.07 € / \mathrm{kWh}_{\mathrm{SNG}}$ under target scenario conditions which assumed a low electrolyzer cost, low stack replacement rate and almost negligible $\mathrm{CO}_{2}$ cost. Under a state-of-art scenario which considers the already achieved best operating parameters for SOEC electrolysis and $88 € / \mathrm{t} \mathrm{CO}_{2}$ cost, the SNG cost at an electricity price of $50 € / \mathrm{MWh}$ is $0.14 € / \mathrm{kWh}_{\mathrm{SNG}}$. Additionally, the authors calculated a specific capital investment of $700 € / \mathrm{kW}_{\mathrm{SNG}}$ for steam electrolysis and $800 € / \mathrm{kW}_{\mathrm{SNG}}$ for co-electrolysis, both of which represent the lowest specific capital costs within the reviewed literature. Furthermore Parra, et al. [23] showed that the levelized cost of SNG substantially decreases with the size of the system. A 33\% cost decrease by increasing the electrolyzer capacity from $1 \mathrm{MW}$ to $1 \mathrm{GW}$ was shown to be due to better efficiency and economies of scale.

The calculated SNG production cost of $0.32 € / \mathrm{kWh}_{\mathrm{th}}\left(0.28 € / \mathrm{kWh}_{\text {th }}\right.$ if considering by-product's sales) is in line with the study of Benjaminsson, et al. [8], which found a SNG cost of $0.24 € / \mathrm{kWh}_{\text {th }}$ for a $1 \mathrm{MW}_{\mathrm{el}}$ PtSNG plant and utilized cost and technical parameters from commercially available equipment. Overall, the estimated costs in this work are in good agreement with literature values; however it is important to highlight that these values represent a big range of operating conditions, production rates, and different levels of detail, as discussed above.

This work's cost estimation method ensures that the economic findings are closely related to the current framework conditions in Germany and if, for example, the regulatory frame in Germany changes in the future, and economic incentives for PtSNG technologies are enforced, the SNG cost and the profitability of the concept could vary. Additionally, the scenario analysis for 2030 only considered capital costs' variations associated with the electrolyzer and not with the chemical plant. This assumption is a source of uncertainty that could be reduced in future studies by considering the forecasted cost increase of material.

\subsection{Environmental}

The global warming potential (GWP) of natural gas, excluding its combustion, amounts to $0.04 \mathrm{~kg} \mathrm{CO}$-eq $/ \mathrm{kWh}_{\text {th }}$, while the GWP of SNG ranges between $-0.17 \mathrm{~kg} \mathrm{CO}$-eq $/ \mathrm{kWh}_{\text {th }}$ and $1.13 \mathrm{~kg} \mathrm{CO}$-eq $/ \mathrm{kWh}_{\text {th }}$ (Figure 9). It has to be stressed that the negative GWP is no indication of a $\mathrm{CO}_{2}$ sink, since the combustion of SNG is not included in the system boundary. The results of the impact assessment indicate that electrolysis plays a crucial role in the environmental performance of PtSNG. Therefore, the global warming impact of the produced SNG strongly depends on the generation of the electricity used in the electrolyzer. In comparison to natural gas, only the scenarios Surplus 2030, and Wind 2020 achieve a GWP reduction $\left(217 \mathrm{~g} \mathrm{CO}_{2}\right.$-eq $/ \mathrm{kWh}_{\mathrm{th}}$ decrease $)$ as a result of the exclusive use of renewable electricity from offshore wind power. On the contrary, if the German electricity mix is used (Scenario Ref 2020 and AEL 2020), it leads to a 26-times higher GWP than conventional production, with a slightly higher GWP contribution by the alkaline electrolyzer than the PEM one, due to their specific energy demand (see Table 6). If the forecasted German electricity mix from 2030 is used (Scenario Cement-CC 2030), also higher GWP than conventional production $\left(670 \mathrm{~g} \mathrm{CO}_{2}-\mathrm{eq} / \mathrm{kWh}_{\mathrm{th}}\right.$ increase) is calculated. Findings also suggest that when considering electricity supply from the German power mix, the $\mathrm{CO}_{2}$ origin (biomethane upgrading or cement plant) has limited impact on the overall fuel GWP. This impact of the $\mathrm{CO}_{2}$ source changes, when the renewable share in electricity production increases. In Scenario Cement-CC 2030, the selected $\mathrm{CO}_{2}$ source reduces the total GWP only by $6 \%$, whereas the impact of electrolysis using 2030s German electricity mix is higher than that of natural gas extraction and distribution. The process steps of the methanation unit itself, the SNG upgrading step and potential $\mathrm{CO}_{2}$ transport (i.e., $50 \mathrm{~km}$ distance between the $\mathrm{CO}_{2}$ capture and SNG plant was assumed) have a negligible impact on the GWP. 


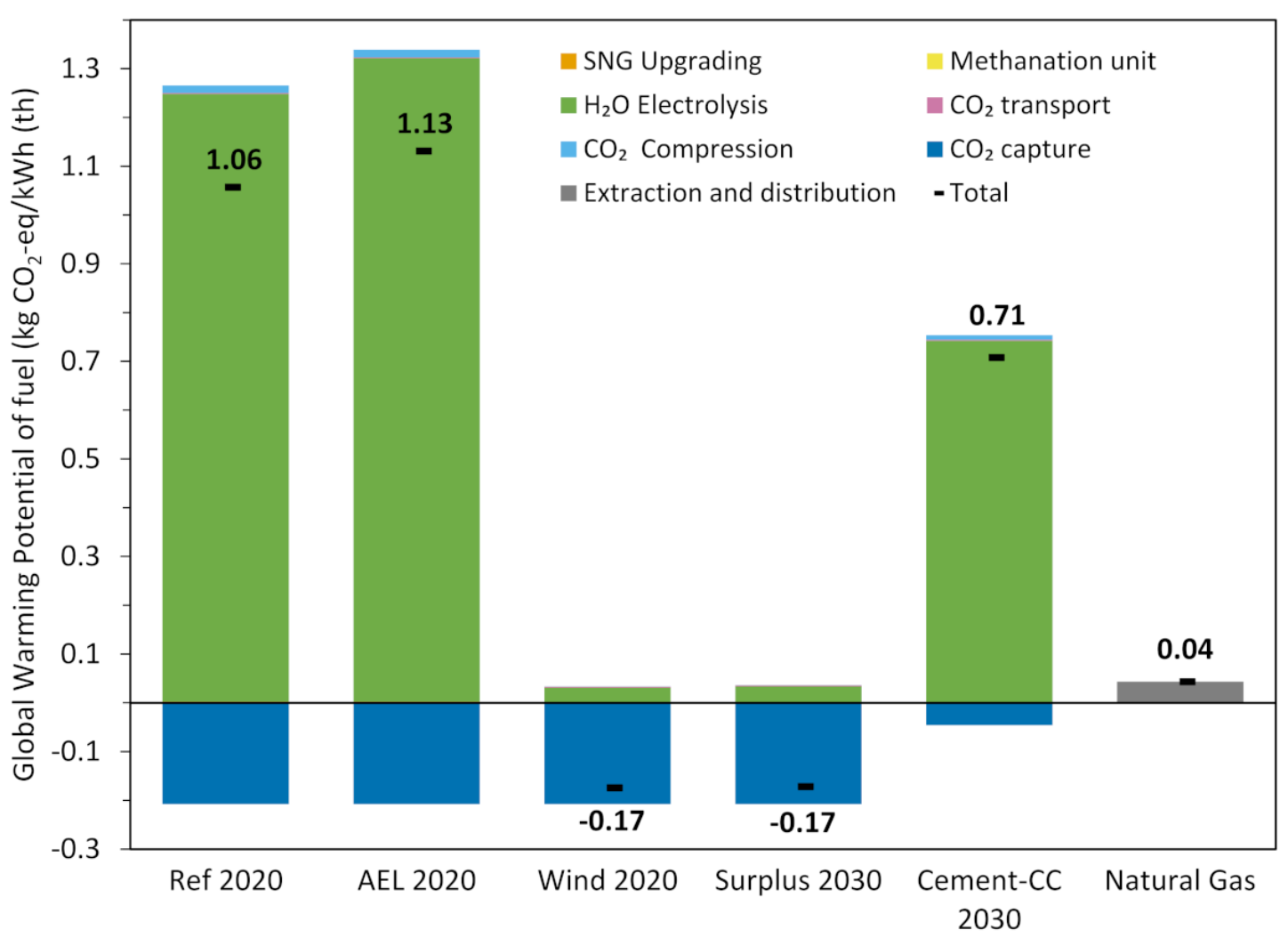

Figure 9. GWP of fuel in conventional and $\mathrm{CO}_{2}$-based pathways. Life cycle inventory is stated in the Supplementary Materials Section S8.

Thus, Power-to-SNG processes which do not utilize a primary renewable electricity supply are expected to lead to larger GHG emissions than conventional natural gas production in 2020 and even in 2030, mainly due to the high emission factor of the electricity supply. In general, the SNG upgrading unit, the $\mathrm{CO}_{2}$ compression step, and the methanation unit of the Power-to-SNG process contribute only on a minor extent to the global warming potential.

For a holistic view of the environmental consequences of Power-to-SNG, further impact categories should be considered. In Figure 10, the categories acidification, eutrophication (freshwater, marine, and terrestrial), human toxicity (cancer effects and non-cancer effects), ionizing radiation, and ozone depletion are depicted for all scenarios relative to the highest result in each category. As with the GWP, the electricity source is also decisive for the performance in other impact categories. For instance, the scenarios using the current electricity grid mix (Ref 2020, AEL 2020) or the electricity grid mix forecast for 2030 (Cement-CC 2030) result in the highest environmental impacts, except for the category ozone depletion. This can be mainly attributed to the electricity production using lignite and hard coal, which still has a share of $18.8 \%$ in the 2030 grid mix forecast, or to the nuclear share of electricity production in case of the ionizing radiation potential (Ref 2020, AEL 2020). For the former, the treatment of spoil from lignite mining in surface landfills is the main cause for the impact categories of eutrophication (freshwater, marine) and human toxicity (cancer and non-cancer effects). By selecting wind power as electricity source (Wind 2020, Surplus 2030), the environmental effect on each investigated impact category is reduced. In this case, the copper, steel and concrete demand for wind power construction impacts the considered categories the most. However, only in the category of ozone depletion is the environmental impact of Power-to-SNG with wind power below that of natural gas. In addition, this is the only category where the electricity source is not the main cause of the impact, since the Nafion content (and its tetrafluoroethylene precursor) in the PEM stack has a similar share in case of Wind 2020 or Surplus 2030 scenario. 


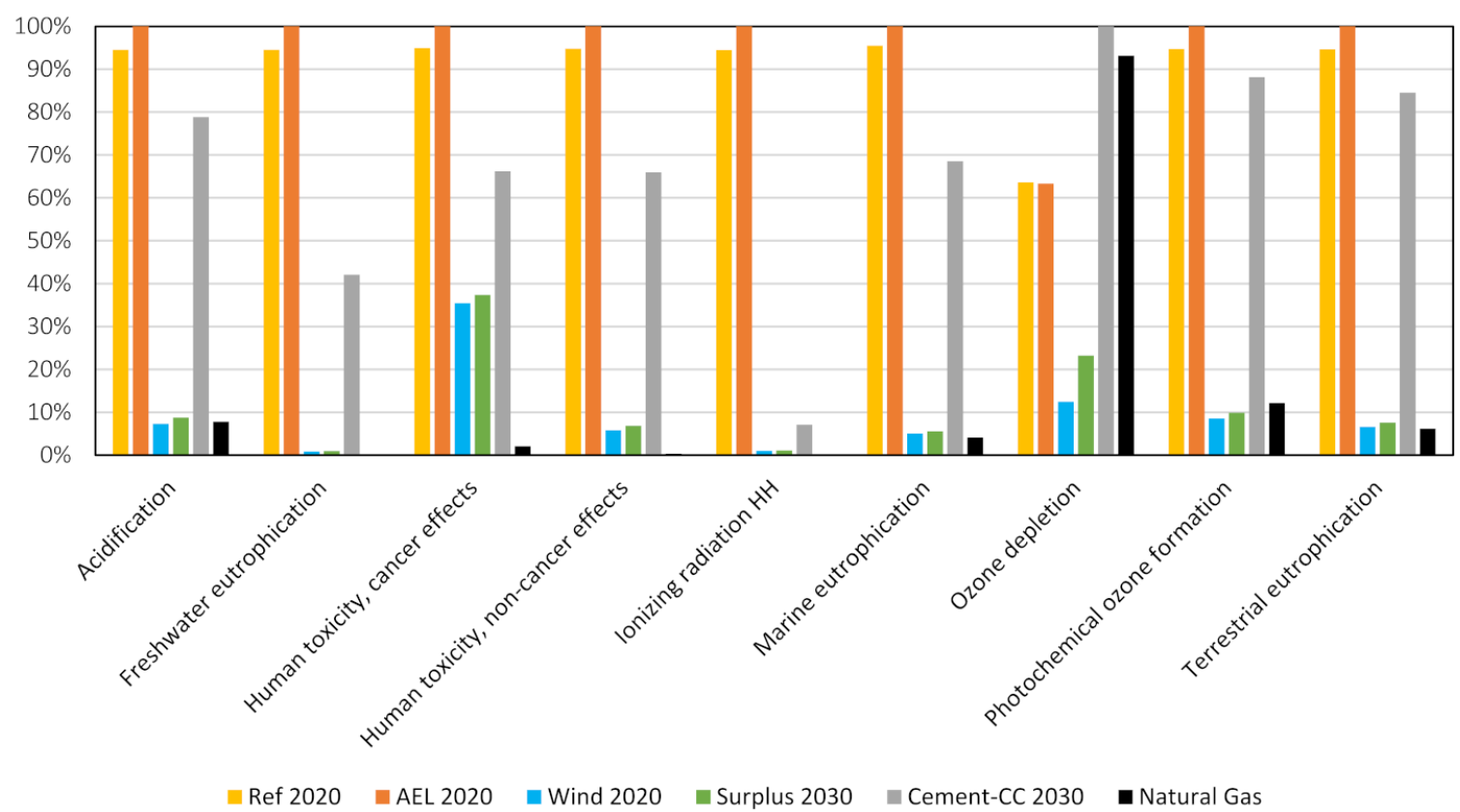

Figure 10. Life cycle impact assessment (cradle-to-gate) of all scenarios in comparison to natural gas. The values are relative to the highest impact of a scenario for each impact category.

\subsection{Sensitivity Analysis}

This section shows how the SNG net cost of production is affected by economic assumptions and how the emissions change with the underlying emission factor for the electricity, by means of sensitivity analyses. Several parameters were varied to determine SNG production cost considering the Reference case. Figure 11 illustrates the obtained results for a plant operating $8000 \mathrm{~h}$ annually.

\section{$\mathrm{C}_{\mathrm{SNG}}(€ / \mathrm{kWh})$}
0.20
0.23
0.26
0.29
0.32
0.35
0.38
0.41
0.44
0.47

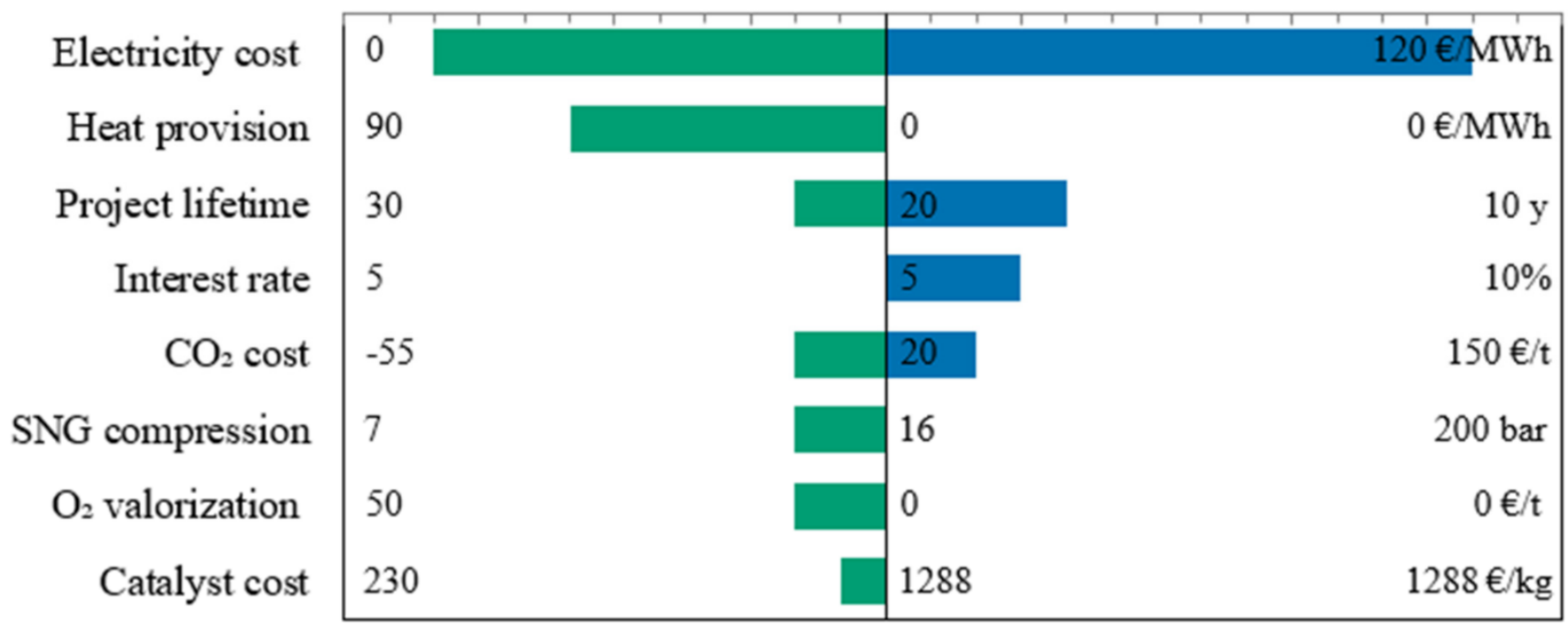

Figure 11. Sensitivity analysis of the PtSNG plant's Reference case.

The electricity cost has the strongest influence on the SNG production cost. When the electricity is supplied free of charge, the SNG NPC reaches a minimum of $0.22 € / \mathrm{kWh}_{\text {th }}$, representing a 31\% decrease from the reference value. By contrast, for a cost of electricity of $120 € / \mathrm{MWh}$, which represents an electricity supply cost including German electricity 
taxes, the fuel cost rises by $40 \%$. As a result of the high capital cost share and therefore its impact on the ACC and SNG NPC, project life, and capital interest rate are meaningful in the fuel cost determination. When the project life is reduced to 10 years, SNG cost rises by $12 \%$, whereas a project lifetime of 30 years decreases SNG cost by $13 \%$. Similarly, an augmented interest rate of $10 \%$ leads to a SNG cost increase of $13 \%$. In terms of revenues from by-products, heat provision has a larger potential for cost reduction than $\mathrm{O}_{2}$ sales. Heat provision can achieve a $17 \%$ fuel cost reduction when charging $90 € / \mathrm{MWh}$, while oxygen sales at a maximum market price of $50 € / \mathrm{t}$ only reduce the SNG cost by $3 \%$.

Economic parameters such as $\mathrm{CO}_{2}$ cost, SNG compression, and catalyst cost have a limited impact on SNG NPC. A $\mathrm{CO}_{2}$ price of $-55 € / \mathrm{t}$, which implies that the PtSNG plant is paid for consuming $\mathrm{CO}_{2}$, only reduces the reference SNG cost by $7 \%$. Whereas, a $\mathrm{CO}_{2}$ cost of $150 € / \mathrm{MWh}$, which considers carbon capture at a power plant or industrial facility, increases the fuel cost by $7 \%$. SNG compression for subsequent injection in the gas grid also has a minor impact on the resulting SNG NPC. Considering an SNG compression to 200 bar, for which only a more powerful compressor and no additional equipment is required, no significant fuel cost increase is found. A potential explanation is that the cost increase of the compressor and the electricity demand are not large enough to have a meaningful impact on the SNG NPC. However, if the SNG is injected in the gas grid at 7 bar, no gas compressor is required, and the SNG cost reduces by 7\%. Even with a substantial catalyst cost reduction (82\%) from the reference value, SNG cost only decreases by $3 \%$. Results indicate that a comprehensive optimization considering all the aforementioned economic parameters permits an extensive SNG cost reduction.

Since the environmental impacts from electricity supply in Germany are planned to be reduced in the future, the effect from electricity supply on PtSNG scenarios is studied in detail and an environmental threshold value for electricity supply is derived. Figure 12 illustrates the GWP of natural gas fossil-based production and PtSNG processes as a function of the $\mathrm{CO}_{2}$-equivalent emission factor of electricity supply. For all PtSNG scenarios, the emission factor of electricity supply has a strong influence on the total GWP, as they require large amounts of electricity for hydrogen production via electrolysis. Scenario Wind 2020 and Surplus 2030 are not considered in this analysis, since they operate solely with renewable electricity from wind power and, therefore, a change in the emission factor of the electricity supply from the national network would not affect its total GWP. The intersections between the SNG production per scenario with the conventional natural gas production are the threshold values for the $\mathrm{CO}_{2}$-eq emission factor of the electricity supply. The environmental threshold values are $114 \mathrm{~g} \mathrm{CO}_{2}-\mathrm{eq} / \mathrm{kWh}_{\mathrm{el}}$ for Scenario AEL 2020 and $121 \mathrm{~g} \mathrm{CO}_{2}$-eq/ $\mathrm{kWh}_{\mathrm{el}}$ for Scenarios Ref 2020 and Surplus 2030. Scenario Cement-CC 2030 requires a "less pollutant" electricity supply (threshold of $46 \mathrm{~g} \mathrm{CO}_{2}$-eq/ $\mathrm{kWh}_{\mathrm{el}}$ ) to achieve the same GWP as natural gas, because of its increased electricity and heat demand in the $\mathrm{CO}_{2}$ capture step. Electricity supply with a $\mathrm{CO}_{2}$-eq emission factor lower than the environmental threshold is expected to be achieved after 2050, based on the forecast for the German electricity mix [69]. Thus, in this timeframe PtSNG utilizing German electricity from the power grid would be environmentally beneficial than natural gas production with regard to the GWP.

Reiter and Lindorfer [19] utilized a cradle-to-gate approach and identified an electricity supply environmental threshold value of $113 \mathrm{~g} \mathrm{CO}_{2}$-eq/ $\mathrm{kWh}_{\mathrm{el}}$ when $\mathrm{CO}_{2}$ capture was neglected and $73 \mathrm{~g} \mathrm{CO}_{2}-\mathrm{eq} / \mathrm{kWh}_{\mathrm{el}}$ if $\mathrm{CO}_{2}$ separation was accounted for. Similarly, Sternberg and Bardow [20] used a cradle-to-gate approach to quantify the electricity supply's environmental threshold and reported a value of $82 \mathrm{~g} \mathrm{CO}_{2}$-eq/ $/ \mathrm{kWh}_{\mathrm{el}}$, including $\mathrm{CO}_{2}$ capture from a coal power plant. Differences between the threshold values obtained for the electricity supply's $\mathrm{CO}_{2}$-eq emission factor in this study and in literature are attributed to the methods and functional units utilized. Available literature also identified that electricity supply has a dominant impact on the GWP of SNG, and found that electrolysis with renewable energy sources reduces the GWP of PtSNG compared to that of the conventional production of natural gas [19-21,23,70]. Overall, this environmental assessment showed that the proposed 
PtSNG plant concept is environmentally beneficial to conventional natural gas production with regards to the global warming potential when renewable energy is used or when the electricity supply has an emission factor lower than $121 \mathrm{~g} \mathrm{CO}_{2}$-eq $/ \mathrm{kWh}_{\mathrm{el}}$.

The following findings can be summarized from the sensitivity analyses: the electricity cost is the main cost component, but even when assuming electricity at no charge comparatively high costs are obtained. This is an indication that much more severe financial support or taxation of conventional processes are necessary to enter a regime of cost competitiveness. Concerning the environmental impact, an almost entirely PV or wind powered operation is required to achieve a reduction of emissions. However, this comes with significant limitations in the operational hours and would require batteries, shifting the focus to the economic aspect again.

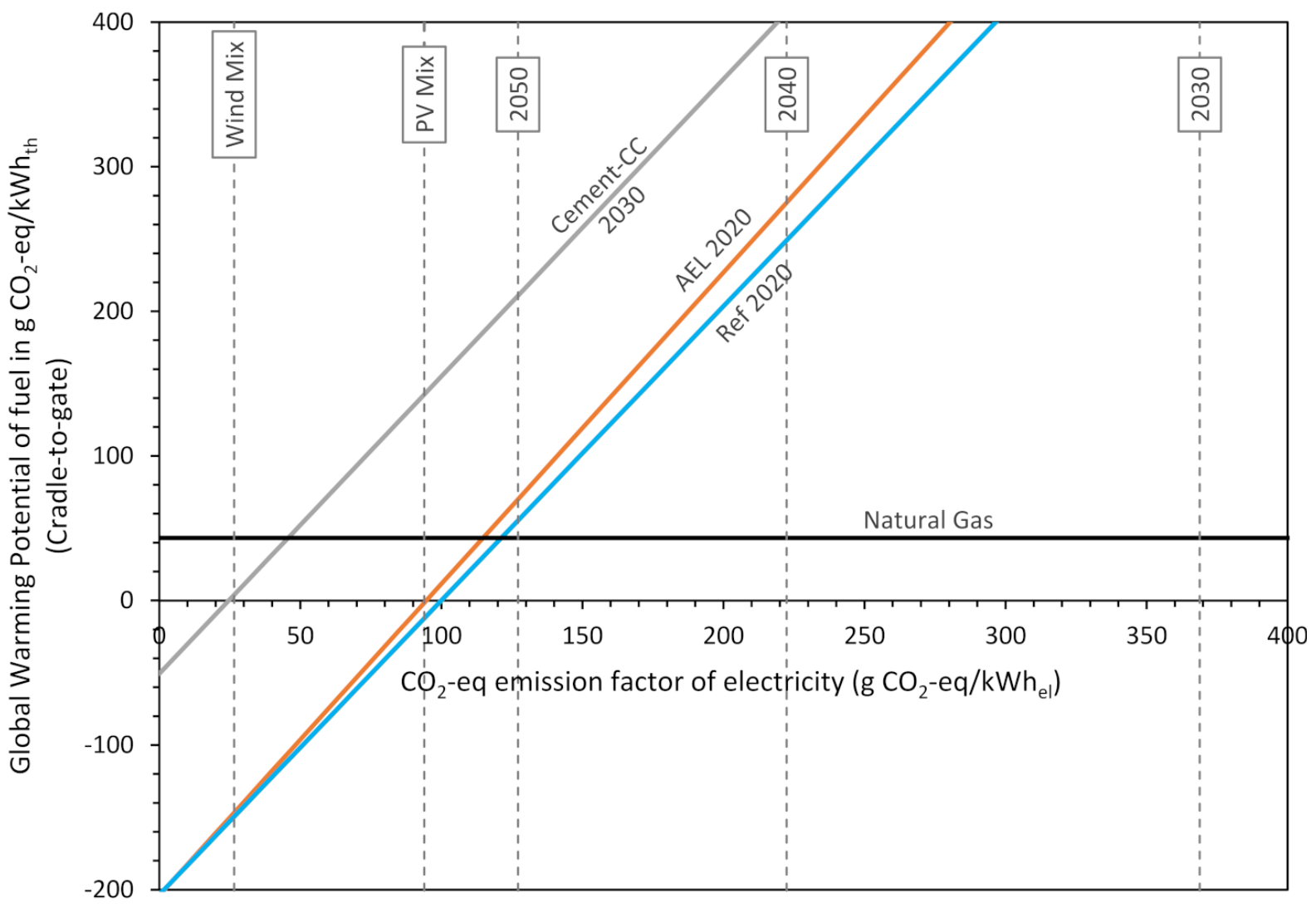

Figure 12. Global warming potential of PtSNG scenarios and conventional natural production as a function of $\mathrm{CO}_{2}$ emission factor of electricity supply. The vertical lines represent the $\mathrm{CO}_{2}$ emission factors of electricity supply from the forecasted German electricity mixes as described in the Supplementary Materials Section S8.

\section{Conclusions}

SNG plants are the second most analyzed PtG option in Germany after hydrogen, which is supported by its technical feasibility and efficiency, as shown in this study. However, considering that none of the plants is operated profitably and many are still in the demo stage, questions arise regarding if and when this technology will be widely employed. In addition, its environmental footprint is a major criterion to avoiding additional damage to the atmosphere than the status quo.

Thus, we aimed to answer two open points in this context: First, what is the cost of a $1 \mathrm{MW}_{\mathrm{el}} \mathrm{SNG}$ plant and what are the sensitive parameters? Second, what is the environmental footprint of such a plant and at which electricity footprint is it more sustainable than natural gas? 
The economic analysis shows that the impact of the $\mathrm{CO}_{2}$ price is negligible while the electricity cost is the main component. However, even when considering electricity at no charge and 8000 full-load operational hours, the cost for a $1 \mathrm{MW}_{\mathrm{el}}$ plant is far from being competitive (0.22 vs. $\left.0.02-0.06 € / \mathrm{kWh}_{\text {th }}\right)$, making a de-centralized deployment unlikely. Taking the results from Parra, et al. [18] as a reference, an increase from $1 \mathrm{MW}$ to $1 \mathrm{GW}$ would decrease this price by $33 \%$ to $0.15 € / \mathrm{kWh}_{\text {th }}$. These findings are related to the regulatory frame, since economic incentives could modify the estimated SNG cost in this study. The Power-to-Gas technology currently finds itself in the so-called valley of death, where the financial support is not enough to cover the required innovation acceleration and up-scaling needs [71]. As a result of the high capital intensity of the technology, the financial risk for first movers entering the competitive gas market is significant and therefore discouraging for new investments. Support schemes that target the supply side of green gases and in particular investment subsidies could lead to a reduction of CAPEX and aid the technology's commercial development. A further option could be to address the demand side with a defined quota for the usage of SNG instead of natural gas. Additionally, the EU emissions trading system (EU ETS) could serve as a mechanism to generate funds, but under no circumstances would the taxation of natural gas solely increase the competitiveness of SNG.

The technical analysis shows that the process can be considered as quite mature. Thus, future studies should shift their focus to a system analysis concerning the future energy and feedstock supply rather than on the methanation technology itself. This will help to identify the sectors and processes, where going away from natural gas as a feedstock is very hard to achieve. Considering biogas as the major alternative to SNG, covering the high demand will in the long run turn out in favor of SNG-especially based on $\mathrm{CO}_{2}$ from fossil sources or captured from the atmosphere. This is particularly true considering that in many regions of the world the availability of biomass and biogas is limited, and also taking into account that other forms of renewable energy, in particular solar energy, exhibit capacities and area specific yields which are significantly higher than those of biogenic resources.

The first priority should be to use the SNG in the chemical industry as a raw material or in industry applications where hydrocarbons will still be an essential feedstock for several reasons (reducing atmospheres required, specific flame properties needed, carbon takes part in a reaction or is part of the product, etc.), but where fossil fuels cannot be used anymore in the mid-to-long-term. Industry is already searching for options to replace the currently used fossil fuels or to even replace the technology entirely. Only as a second priority should such fuels be used for mobility.

The environmental analysis shows that currently only scenarios for operation with wind energy decrease the emissions compared to natural gas, while PV has a limited impact. However, in such cases the operational hours would decrease significantly, or batteries would have to be employed, making the operation highly uneconomical. Thus, the only solution to cover the demand while having high operational hours is the decarbonization of the electricity grid. The sensitivity study shows that the emission factor of the electricity has to decrease below $121 \mathrm{~g} \mathrm{CO}_{2}-\mathrm{eq} / \mathrm{kWh}_{\text {th }}$ to match the footprint of natural gas. A similar value was found by other studies. This level will be reached in Germany after 2050 [69], which can be considered as the time horizon to scale up all the relevant technologies.

Supplementary Materials: The following supporting information can be downloaded at: https:/ / www.mdpi.com/article/10.3390/en15051608/s1, Table S1: Stream tables of PtSNG plant's simulation; Table S2: Lang-factors for estimating FCI on the basis of EC, adapted from Peters, et al. [1]; Table S3: Summary of plant equipment sizing; Table S4: Equipment cost estimation parameters; Table S5: Method for the estimation of fixed production costs.; Table S6: Base case NPC estimation summary:; Table S7: Compilation of literature utilized for the SNG cost comparison.; Table S8: Natural gas price in Germany. Prices include taxes for private and industrial customers, but not for cross-border.; Table S9: Definition of electricity scenarios in the life cycle analysis.; Table S10: Life cycle inventory for a 1 MWth SNG plant. 


\begin{abstract}
Author Contributions: Conceptualization, E.V.P. and G.M.; Funding acquisition, C.S.; Investigation, E.V.P. and N.C.N.; Supervision, G.M., M.R. and A.A.; Writing—original draft, E.V.P.; Writing—review \& editing, E.V.P., G.M., N.C.N., M.R., A.A. and C.S. All authors have read and agreed to the published version of the manuscript.
\end{abstract}

Funding: This study has been carried out in the frame of project CCU-Akzelerator (EFO 0012B). The funding of the NRW-Ministry of Economic Affairs, Innovation, Digitalization and Energy through the IN4climate. NRW initiative is gratefully acknowledged.

Institutional Review Board Statement: Not applicable.

Informed Consent Statement: Not applicable.

Data Availability Statement: Not applicable.

Conflicts of Interest: The authors declare no conflict of interest. The funders had no role in the design of the study; in the collection, analyses, or interpretation of data; in the writing of the manuscript, or in the decision to publish the results.

\title{
References
}

1. Federal German Government. Climate Change Act 2021. 2021. Available online: https://www.legislation.gov.uk/ (accessed on 1 January 2022).

2. Schemme, S.; Breuer, J.L.; Köller, M.; Meschede, S.; Walman, F.; Samsun, R.C.; Peters, R.; Stolten, D. H2-based synthetic fuels: A techno-economic comparison of alcohol, ether and hydrocarbon production. Int. J. Hydrogen Energy 2020, 45, 5395-5414. [CrossRef]

3. Götz, M.; Lefebvre, J.; Mörs, F.; McDaniel Koch, A.; Graf, F.; Bajohr, S.; Reimert, R.; Kolb, T. Renewable Power-to-Gas: A technological and economic review. Renew. Energy 2016, 85, 1371-1390. [CrossRef]

4. DVGW. Wo aus Wind und Sonne Grünes Gas Wird... Eine Übersicht der Power-to-Gas-Projekte in Deutschland. 2019. Available online: https://www.dvgw.de/medien/dvgw/verein/energiewende/bilder/karte-power-to-gas-anlagen.pdf (accessed on 1 January 2022).

5. Wulf, C.; Linßen, J.; Zapp, P. Review of Power-to-Gas Projects in Europe. Energy Procedia 2018, 155, 367-378. [CrossRef]

6. DENA. Strategieplattform Power to Gas: Projektkarte. 2020. Available online: https://www.powertogas.info/projektkarte/ (accessed on 1 January 2022).

7. Bailera, M.; Lisbona, P.; Romeo, L.M.; Espatolero, S. Power to Gas projects review: Lab, pilot and demo plants for storing renewable energy and $\mathrm{CO}_{2}$. Renew. Sustain. Energy Rev. 2017, 69, 292-312. [CrossRef]

8. Benjaminsson, G.; Benjaminsson, J.; Rudberg, R. Power-to-Gas-A technical review. Malmö Sven. Gastek. Cent. AB 2013, 284, 13-64.

9. De Saint Jean, M.; Baurens, P.; Bouallou, C. Parametric study of an efficient renewable power-to-substitute-natural-gas process including high-temperature steam electrolysis. Int. J. Hydrogen Energy 2014, 39, 17024-17039. [CrossRef]

10. De Saint Jean, M.; Baurens, P.; Bouallou, C.; Couturier, K. Economic assessment of a power-to-substitute-natural-gas process including high-temperature steam electrolysis. Int. J. Hydrogen Energy 2015, 40, 6487-6500. [CrossRef]

11. König, D.H.; Freiberg, M.; Dietrich, R.-U.; Wörner, A. Techno-economic study of the storage of fluctuating renewable energy in liquid hydrocarbons. Fuel 2015, 159, 289-297. [CrossRef]

12. Albrecht, F.G.; König, D.H.; Baucks, N.; Dietrich, R.-U. A standardized methodology for the techno-economic evaluation of alternative fuels-A case study. Fuel 2017, 194, 511-526. [CrossRef]

13. Michailos, S.; McCord, S.; Sick, V.; Stokes, G.; Styring, P. Dimethyl ether synthesis via captured $\mathrm{CO}_{2}$ hydrogenation within the power to liquids concept: A techno-economic assessment. Energy Convers. Manag. 2019, 184, 262-276. [CrossRef]

14. Tremel, A.; Wasserscheid, P.; Baldauf, M.; Hammer, T. Techno-economic analysis for the synthesis of liquid and gaseous fuels based on hydrogen production via electrolysis. Int. J. Hydrogen Energy 2015, 40, 11457-11464. [CrossRef]

15. Schiebahn, S.; Grube, T.; Robinius, M.; Tietze, V.; Kumar, B.; Stolten, D. Power to gas: Technological overview, systems analysis and economic assessment for a case study in Germany. Int. J. Hydrogen Energy 2015, 40, 4285-4294. [CrossRef]

16. Buchholz, O.S.; van der Ham, A.G.J.; Veneman, R.; Brilman, D.W.F.; Kersten, S.R.A. Power-to-Gas: Storing Surplus Electrical Energy. A Design Study. Energy Procedia 2014, 63, 7993-8009. [CrossRef]

17. Giglio, E.; Deorsola, F.A.; Gruber, M.; Harth, S.R.; Morosanu, E.A.; Trimis, D.; Bensaid, S.; Pirone, R. Power-to-Gas through High Temperature Electrolysis and Carbon Dioxide Methanation: Reactor Design and Process Modeling. Ind. Eng. Chem. Res. 2018, 57, 4007-4018. [CrossRef]

18. Parra, D.; Patel, M.K. Techno-economic implications of the electrolyser technology and size for power-to-gas systems. Int. J. Hydrog. Energy 2016, 41, 3748-3761. [CrossRef]

19. Reiter, G.; Lindorfer, J. Global warming potential of hydrogen and methane production from renewable electricity via power-to-gas technology. Int. J. Life Cycle Assess. 2015, 20, 477-489. [CrossRef] 
20. Sternberg, A.; Bardow, A. Life Cycle Assessment of Power-to-Gas: Syngas vs Methane. ACS Sustain. Chem. Eng. 2016, 4, 4156-4165. [CrossRef]

21. Hoppe, W.; Bringezu, S.; Thonemann, N. Comparison of global warming potential between conventionally produced and CO2-based natural gas used in transport versus chemical production. J. Clean. Prod. 2016, 121, 231-237. [CrossRef]

22. Collet, P.; Flottes, E.; Favre, A.; Raynal, L.; Pierre, H.; Capela, S.; Peregrina, C. Techno-economic and Life Cycle Assessment of methane production via biogas upgrading and power to gas technology. Appl. Energy 2017, 192, 282-295. [CrossRef]

23. Parra, D.; Zhang, X.; Bauer, C.; Patel, M.K. An integrated techno-economic and life cycle environmental assessment of power-togas systems. Appl. Energy 2017, 193, 440-454. [CrossRef]

24. Aspen Technology Inc. Aspen Plus. USA. 2021. Available online: https://www.aspentech.com/en/products/engineering/ aspen-plus (accessed on 1 January 2022).

25. DVGW. Technische Regel-Arbeitsblatt DVGW G 260 (A); DVGW: Bonn, Germany, 2013.

26. Peters, R.; Baltruweit, M.; Grube, T.; Samsun, R.C.; Stolten, D. A techno economic analysis of the power to gas route. J. CO2 Util. 2019, 34, 616-634. [CrossRef]

27. König, D.H.; Baucks, N.; Dietrich, R.-U.; Wörner, A. Simulation and evaluation of a process concept for the generation of synthetic fuel from $\mathrm{CO}_{2}$ and $\mathrm{H}_{2}$. Energy 2015, 91, 833-841. [CrossRef]

28. NOW GmbH. Studie IndWEDe-Kurzfassung Industrialisierung der Wasserelektrolyse in Deutschland: Chancen und Herausforderungen für Nachhaltigen Wasserstoff für Verkehr, Strom und Wärme; NOW GmbH: Berlin, Germany, 2018.

29. Solar Fuel GmbH. Hocheffizientes Verfahren zur katalytischen Methanisierung von Kohlendioxid und Wasserstoffenthaltenden Gasgemischen; Markenamt, D., Ed.; Hitachi Zosen Inova Etogas GmbH: Stuttgart, Germany, 2011

30. Rönsch, S.; Schneider, J.; Matthischke, S.; Schlüter, M.; Götz, M.; Lefebvre, J.; Prabhakaran, P.; Bajohr, S. Review on methanationFrom fundamentals to current projects. Fuel 2016, 166, 276-296. [CrossRef]

31. Porubova, J.; Bazbauers, G.; Markova, D. Modeling of the Adiabatic and Isothermal Methanation Process. Environ. Clim. Technol. 2011, 6, 79-84. [CrossRef]

32. Schlereth, D.; Hinrichsen, O. A fixed-bed reactor modeling study on the methanation of $\mathrm{CO}_{2}$. Chem. Eng. Res. Des. 2014, 92, 702-712. [CrossRef]

33. Kuznik, F. Energy Storage by Adsorption Technology for Building. In Handbook of Energy Systems in Green Buildings; Wang, R., Zhai, X., Eds.; Springer: Berlin/Heidelberg, Germany, 2018; pp. 1-27. [CrossRef]

34. Falbo, L.; Martinelli, M.; Visconti, C.G.; Lietti, L.; Bassano, C.; Deiana, P. Kinetics of $\mathrm{CO}_{2}$ methanation on a Ru-based catalyst at process conditions relevant for Power-to-Gas applications. Appl. Catal. B Environ. 2018, 225, 354-363. [CrossRef]

35. Lunde, P.J.; Kester, F.L. Carbon Dioxide Methanation on a Ruthenium Catalyst. Ind. Eng. Chem. Process Des. Dev. 1974, 13, 27-33. [CrossRef]

36. Bassano, C.; Deiana, P.; Lietti, L.; Visconti, C.G. P2G movable modular plant operation on synthetic methane production from CO2 and hydrogen from renewables sources. Fuel 2019, 253, 1071-1079. [CrossRef]

37. Ulrich, G.D.; Vasudevan, P.T. Chemical Engineering Process Design and Economics: A Practical Guide, 2nd ed.; Taylor \& Francis Group: Abingdon-on-Thames, UK, 2004.

38. Linnhoff, B.; Hindmarsh, E. The pinch design method for heat exchanger networks. Chem. Eng. Sci. 1983, 38, 745-763. [CrossRef]

39. Brynolf, S.; Taljegard, M.; Grahn, M.; Hansson, J. Electrofuels for the transport sector: A review of production costs. Renew. Sustain. Energy Rev. 2018, 81, 1887-1905. [CrossRef]

40. Billig, E.; Decker, M.; Benzinger, W.; Ketelsen, F.; Pfeifer, P.; Peters, R.; Stolten, D.; Thrän, D. Non-fossil CO $\mathrm{CO}_{2}$ recycling-The technical potential for the present and future utilization for fuels in Germany. J. CO2 Util. 2019, 30, 130-141. [CrossRef]

41. Becker, W.L.; Penev, M.; Braun, R.J. Production of Synthetic Natural Gas From Carbon Dioxide and Renewably Generated Hydrogen: A Techno-Economic Analysis of a Power-to-Gas Strategy. J. Energy Resour. Technol. 2018, 141. [CrossRef]

42. Towler, G.; Sinnott, R. Chemical engineering Design: Principles, Practice, and Economics of Plant and Process Design, 2nd ed.; Butterworth-Heinemann: Boston, MA, USA, 2013. [CrossRef]

43. Association of the Advancement of Cost Engineering. Cost Estimate Classification System-As Applied in Engineering, Procurement, and Construction for the Process Industries; AACE International: Morgantown, WV, USA, 2011.

44. Peters, M.S.; Timmerhaus, K.D.; West, R.E. Plant Design and Economics for Chemical Engineers, 5th ed.; McGraw-Hill Education: New York, NY, USA, 2003.

45. Jenkins, S. Chemical Engineering Plant Cost Index: 2018 Annual Value. Access Intelligence LLC. 2019. Available online: https:/ / www.chemengonline.com/2019-cepci-updates-january-prelim-and-december-2018-final/ (accessed on 1 January 2022).

46. European Central Bank. ECB Euro Reference Exchange Rate: US Dollar (USD); European Central Bank: Frankfurt, Germany, 2020.

47. Pichlmaier, S.; Regett, A.; Kigle, S.; Haas, S.; Feinauer, M.; Oswald, M. Ökobilanzen Synthetischer Kraftstoffe Methodikleitfaden; Begleitsforschung Energiewende im Verkehr: München, Germany, 2020.

48. Viebahn, P.; Horst, J.; Scholz, A.; Zelt, O. Technologiebericht 4.4 Verfahren der $\mathrm{CO}_{2}$-Abtrennung aus Faulgasen und Umgebungsluft; Wuppertal Institut I, IZES (Hrsg.), Technologien für die Energiewende Teilbericht 2 an das Bundesministerium für Wirtschaft und Energie (BMWi): Wuppertal/Karlsruhe/Saarbrücken, Germany, 2018.

49. Fu, Q.; Mabilat, C.; Zahid, M.; Brisse, A.; Gautier, L. Syngas production via high-temperature steam/CO2 co-electrolysis: An economic assessment. Energy Environ. Sci. 2010, 3, 1382-1397. [CrossRef] 
50. Panos, K. Praxisbuch Energiewirtschaft: Energieumwandlung, -Transport und -Beschaffung im Liberalisierten Markt; Springer: Berlin/Heidelberg, Germany, 2008.

51. Wirth, H. Recent Facts about Photovoltaics in Germany; Fraunhofer ISE: Freiburg, Germany, 2021.

52. Fraunhofer IWES. The European Power System in 2030: Flexibility Challenges and Integration Benefits. An Analysis with a Focus on the Pentalateral Energy Forum Region; Agora Energiewende: Berlin, Germany, 2015.

53. IRENA. Renewable Power Generation Costs in 2019; IRENA: Abu Dhabi, United Arab Emirates, 2020.

54. Hein, F.; Peter, F.; Graichen, P. The German Power Market State of Affairs in 2019; Agora Energiewende: Berlin, Germany, 2020.

55. Lewis, M. Closing the Gap to a Paris Compliant EU-ETS; Carbon Tracker: London, UK, 2018.

56. Swiss Centre for Life Cycle Inventories. Life Cycle Inventories of Chemicals; Ecoinvent Centre: Dübendorf, Switzerland, 2007.

57. EWI Energy Research and Scenarios. The Energy Market in 2030 and 2050-The Contribution of Gas and Heat Infrastructure to Efficient Carbon Emission Reductions; ewi ERS: Köln, Germany, 2018.

58. Kuramochi, T.; Ramírez, A.; Turkenburg, W.; Faaij, A. Comparative assessment of $\mathrm{CO}_{2}$ capture technologies for carbon-intensive industrial processes. Prog. Energy Combust. Sci. 2012, 38, 87-112. [CrossRef]

59. Lotrič, A.; Sekavčnik, M.; Kuštrin, I.; Mori, M. Life-cycle assessment of hydrogen technologies with the focus on EU critical raw materials and end-of-life strategies. Int. J. Hydrogen Energy 2021, 46, 10143-10160. [CrossRef]

60. Bareiß, K.; de la Rua, C.; Möckl, M.; Hamacher, T. Life cycle assessment of hydrogen from proton exchange membrane water electrolysis in future energy systems. Appl. Energy 2019, 237, 862-872. [CrossRef]

61. Elbe Energie. Erdgaspreise: Preisanstieg bis 2030 um 35\%. 2022. Available online: https://www.elbe-energie.de/erdgaspreisepreisanstieg-bis-2030-um-35-erwartet/ (accessed on 1 January 2022).

62. Gibgas. Fakten-Preisfindung. 2020. Available online: www.gibgas.de\%2Fincl\%2Fdownload\%2Fegt_preisfinder.xls\&usg= AOvVaw0Gy848NN4UxgZJk0cqCD20 (accessed on 1 January 2022).

63. Zauner, A.; Rosenfeld, D.; Tichler, R. Analysis on future technology options and on techno-economic optimization. Store E Go 2019, 7, 2-89.

64. Giglio, E.; Lanzini, A.; Santarelli, M.; Leone, P. Synthetic natural gas via integrated high-temperature electrolysis and methanation: Part II-Economic analysis. J. Energy Storage 2015, 2, 64-79. [CrossRef]

65. Jentsch, M.; Trost, T.; Sterner, M. Optimal Use of Power-to-Gas Energy Storage Systems in an 85\% Renewable Energy Scenario. Energy Procedia 2014, 46, 254-261. [CrossRef]

66. Mohseni, F.; Görling, M.; Alvfors, P. The competitiveness of synthetic natural gas as a propellant in the Swedish fuel market. Energy Policy 2013, 52, 810-818. [CrossRef]

67. Tichler, R.; Steinmüller, H.; Reiter, G. Teilprojekt D “Wirthschaftlichkeit und Systemanalyse von Power-to-Gas-Konzepten; DVGW: Bonn, Germany, 2014.

68. Becker, W.L.; Braun, R.J.; Penev, M.; Melaina, M. Production of Fischer-Tropsch liquid fuels from high temperature solid oxide co-electrolysis units. Energy 2012, 47, 99-115. [CrossRef]

69. Fraunhofer ISE. Wege zu Einem Klimaneutralen Energiesystem-Die Deutsche Energiewende im Kontext Gesellschaftlicher Verhaltensweisen; Fraunhofer ISE: Freiburg, Germany, 2020.

70. von der Assen, N.; Jung, J.; Bardow, A. Life-cycle assessment of carbon dioxide capture and utilization: Avoiding the pitfalls. Energy Environ. Sci. 2013, 6, 2721-2734. [CrossRef]

71. Rasmusson, H.B.; Cigarida, H.; Gerstein, D.; Graf, F.; Isik, V.; Jepma, C.S.; Spijker, E.; Tichler, R.; Veseli, A.; Zauner, A. Roadmap and Policy Recommendations for Power-to-Gas in the EU up to 2050. Available online: https://www.storeandgo.info/fileadmin/ dateien/STORE_GO_power_to_gas_roadmap_update.pdf (accessed on 1 January 2022). 